DOI 10.4467/2543733XSSB.17.001.9976

\author{
DANUTA QUIRINI-POPŁAWSKA
}

Uniwersytet Jagielloński

KRZYSZTOF FRANKOWICZ

Biblioteka Jagiellońska

\title{
DZIELA XVI-WIECZNYCH PADEWSKICH PROFESORÓW PRAWA, FILOZOFÓW I FILOLOGÓW W ZBIORACH BIBLIOTEKI JAGIELLOŃSKIEJ ORAZ ICH PROWENIENCJA
}

\author{
Works of 16th-century Paduan \\ law professors, philosophers and philologists \\ in the collection of the Jagiellonian Library and their provenance
}

Summary

In the introductory part of the article, the authors emphasize the role played by one of the most famous centers of European thought in the Renaissance - University of Padua. They describe the scientific profiles of its six distinguished professors - lawyers, philosophers and philologists: Carlo Sigonio, Francesco Robortello, Jacopo Zabare lla, Marco Mantova Benavides, Antonio Riccoboni and Guido Panciroli. Since the 30s of the 16th century, period of the most extensive contacts between Polish - Lithuanian Commonwealth and the Padua school was recorded, where many of its prominent citizens' so ns continued their studies. The authors discuss the course of their studies, the role they played among numerous international youth, their exercised dignities, and, above all, the degrees achieved. Personal contacts with the Paduan professors, fascination with their knowledge and the scientific atmosphere of then Italy, contributed to the deepening of Polish - Italian scientific contacts. One of their effects was the acquisition of the latest works of the Paduan scholars, which were brought by the Poles to $t$ heir homeland. Most of them over the years have found their place in the Collegium Maius library of the Cracow Academy. Various routes of this transfer were presented in the article on the basis of the archival materials studied at the Archivio Antico in Padua, the extensive foreign and Polish bibliography, but above all in the rich collections of old prints of the Jagiellonian Library, which took over the collections of the Collegium Maius library. The article has been enriched with six illustrations of th e works of the Paduan scholars. 
Keywords: University of Padua, works of law professors, philosophers and philologists, Renaissance, students of Rzeczpospolita, old prints of the Jagiellonian Library.

Słowa kluczowe: Uniwersytet Padewski, dzieła profesorów prawa, filozofów i filologów, renesans, studenci z Rzeczypospolitej, stare druki Biblioteki Jagiellońskiej

Niezmiernie ważnym elementem w rozwoju życia umysłowego Rzeczpospolitej XV-XVI wieku były wyjazdy jej mieszkańców na studia do zagranicznych uniwersytetów, w tym głównie do Włoch. Zarysowujący się już pod koniec XIV w. nowy, prężnie się rozwijający w XV w. prąd umysłowy objął niemal wszystkie dziedziny życia umysłowego Włoch i ogarnął cały obszar Półwyspu Apenińskiego. System niepodważalnych dotąd dogmatów został zastąpiony zmysłem krytycznym, a odkrycie i uwielbienie antyku zaowocowało wspaniałym rozwojem nauki, myśli, sztuki i budownictwa ${ }^{1}$. Zaczęto doceniać tkwiące w człowieku wartości, bez względu na jego pochodzenie społeczne, zaś artyści, uczeni, poeci stawali się obiektem podziwu i zasługiwali na uwielbienie ${ }^{2}$. Zainteresowanie kulturą humanistyczną były wkrótce widoczne we wszystkich państwach europejskich. W Polsce jej symptomy pojawiły się w II połowie XV wieku i wkrótce znalazły wielu zwolenników. Coraz bardziej ciekawił ludzi świat nie tylko bliski, ale i daleki. Nowinki humanistyczne propagowali w Polsce przedstawiciele wcale już licznej grupy emigrantów włoskich. Z autopsji stykali się z ideami humanistycznymi w samej Italii wysyłani przez dwór królewski dyplomaci, duchowni, dalej kupcy, ale przede wszystkim podróżujący scholarzy z rozległego terytorium Korony i Litwy. Bowiem od co najmniej XIII w. włoskie uniwersytety stały się źródłem wiedzy i szkołą polityczną większości elit europejskich, które znalazły się pod przemożnym wpływem nowego prądu umysłowego.

Padwa w czasach Renesansu była jednym z najsławniejszych ośrodków europejskiej myśli naukowej, zdołała utrzymać wysoka, niezmienną i uniwersalną pozycję w XVI-wiecznej rzeczywistości, wysuwając się na czołowe miejsce w życiu uniwersyteckiej Europy. Ta świadomość potęgi intelektualnej ośrodka padewskiego, jego rozwój i nowoczesność sprowadzały do miasta całe zastępy młodzieży europejskiej. Odżyła literatura klasyczna, stając się podstawą rozwoju myśli, polemik i dociekań naukowych. Tworzyły się nowe nauki - filologia oraz historia. Celeberrima per universum orbem Uviversitas Patavina przyciagała także dalekich mieszkańców Polski, którzy podzielali opinię polityka, dyplomaty i kardynała Bernarda Navagero 1507-1565), że Senza lo studio Padua non saria Padua ${ }^{3}$ Na podkreślenie zasługuje też fakt, że Padwa położona była blisko Wenecji, podziwianej z racji perfekcyjnego systemu rządowego, stabilności, doskonałej służby dyplomatycznej

${ }^{1}$ J. Delumeau, Cywilizacja Odrodzenia, Warszawa 1987, s. 82-85, 101 i n.; E. Garin, La cultura del Rinascimento, Bari 1967, s. 23 i n., 158-161.

${ }^{2}$ P. Burke, Kultura i spoleczeństwo w renesansowych Wtoszech, Warszawa 1991, s. 28; J. Burckhardt, Kultura Odrodzenie we Wloszech. Próba ujęcia, Warszawa 1961, s. 191-193, 236; G. Procacci, Storia degli Italiani, t. 2, Roma-Bari 1977, s. 112-117; J. Delumeau, Cywilizacja, s. 248-249, 290-291.

${ }^{3}$ H. Barycz, Spojrzenia w przeszłość polsko-włoska, Wrocław-Warszawa-Kraków 1965, s. 196; D. Santarelli, Navagero Bernardo, [w:] Dizionario Biografio degli Italiani, t. 78, Roma 2013, s. 35-38; Enciclopedia italiana di scienze, lettere ed arti, t. 24, Roma 1934-1943, s. 336; wychowanek Uniwersytetu Padewskiego, podesta Padwy w latach 1546-1548, członek komisji Riformatori dello Studio di Padova w 1553 r., humanista, dyplomata, kardynał w $1560 \mathrm{r}$. 
oraz sprawiedliwego wymiaru sądownictwa. Jak konstatuje Arturo Castiglioni, Senat wenecki w liście z 7 kwietnia 1565 r., skierowanym do króla Zygmunta Augusta, polecał względom króla powracającego do ojczyzny Jana Zamoyskiego oraz zapewniał o otoczeniu protekcją polskich studentów na Uniwersytecie Padewskim: quod singulari amore nobilissimam Polonorum nationem semper dileximus - proviamo uno speciale affetto per la nobile Nazione polacca 4 .

W Uniwersytecie Padewskim od 1399 r. wybierano dwóch odrębnych rektorów spośród członków dwóch funkcjonujących uniwersytetów: prawa - Universitas Iuristarum oraz sztuk wyzwolonych - (skupiający medyków, filozofów oraz teologów) Universitas Artistarum. Równocześnie zaczęły się wyłaniać odrębne nacje, skupiające studentów jednej narodowości. Uniwersytet prawniczy liczył aż 24 nacje, on też (obok uniwersytetu skupiającego artystów) miał prawo wybierać swego rektora, prorektorów, asesorów i konsyliarzy, m.in. 4 sierpnia 1563 na jego rektora został wybrany Jan Zamoyski ${ }^{5}$.

Kadra profesorska Uniwersytetu Padewskiego (od 1404 r.) była mianowana przez władze weneckie, które w 1528 r. powołały specjalną komisję - Riformatori dello studio di Padova i to na jej ręce spływały kandydatury nowych profesorów padewskich. Serenissima łożyła ogromne sumy na Uniwersytet Padewski, sprowadzała najlepszych profesorów i zatrzymywała ich wysokimi pensjami, przyznawała stypendia oraz pokrywała koszty ich wyjazdów naukowo-badawczych. Nominacji profesorów dokonywali doża i Signoria, następnie ich propozycje musiał zaaprobować Senat. Ta działalność i specjalna polityka rządu weneckiego w obsadzaniu katedr, polegająca m.in. na ograniczeniu nominacji przedstawicieli rodzin padewskich na korzyść wyszukiwania i ściagania najlepszych znawców nauki z całej ówczesnej Europy, pozwoliła utrzymać wysoki poziom nauki na uczelni oraz jej prestiż. Reformatorzy czuwali nad pracą profesorów, kontrolując zakres ich działalności dydaktycznej i naukowej, popierając poszukiwanie przez nich nowych dróg rozwoju wiedzy oraz nowatorskich metod dydaktycznych. Dokonywane eksperymenty i najnowsze odkrycia zmieniały obraz tradycyjnej wiedzy, budząc wśród słuchaczy żywe zainteresowanie. $\mathrm{O}$ wprowadzanych zmianach i towarzyszących im nowościach świadczyła szeroka korespondencja między ówczesnymi uczonymi, znajdująca się m.in. w Archivio Antico di Padova i Biblioteca Universitaria di Bologna. Powszechną praktyką było dodawanie do własnych dzieł merytorycznych uwag, krytycznych wypowiedzi, recenzji oraz polemik odnoszących się do najnowszych prac drukowanych swoich kolegów. Obok medycyny, która, jak sądzimy, reprezentowała w Padwie najwyższy poziom europejski, na wysokim poziomie stały: prawo, filozofia oraz powstające nowe gałęzie nauki: filologia - humanio$r a$ oraz historia. Przedstawiciele tych nauk, wyróżniający się nie tylko erudycją i nowatorskimi metodami dydaktycznymi, przyciagali słuchaczy fascynacją i znajomością osiagnięć starożytnych filozofów, a przede wszystkim rzymskiego prawa, wykładanego w nowej humanistycznej interpretacji.

Wśród wybitnych XVI-wiecznych profesorów filozofii oraz szeroko rozumianej filologii, znanej wówczas pod nazwą humaniorów, wymienić trzeba następujące nazwiska:

${ }^{4}$ A. Castiglioni, Gli studenti di medicina polacchi all’Università di Padova, Siena 1933, s. 15; S. Kot, Venezia vista dai Polacchi nel corso dei secoli, Venezia 1947, s. 18; Archiwum Jana Zamoyskiego, kanclerza $i$ hetmana wielkiego koronnego, t. 1 1553-1579, wyd. W. Sobieski, Warszawa 1904, nr 6.

${ }^{5}$ Archiwum Jana Zamoyskiego, t. I, nr 7, s. 396; H. Barycz, Spojrzenia w przeszłość, s. 241; F. Lane, Storia di Venezia, Torino 1978, s. 255. 
Carlo Sigonio (1520-1584)

Francesco Robortello (1516-1567)

Jacopo Zabarella (1533-1589)

oraz profesorów prawa:

Marco Mantova Benavides (1489-1582)

Antonio Riccoboni (1541-1599)

Guido Panciroli (1523-1599).

Od lat trzydziestych XVI wieku rozpoczyna się najżywszy okres kontaktów Polaków z Uniwersytetem Padewskim, który przyniósł liczne grono wykształconych polskich prawników, filologów, filozofów, historyków oraz medyków. Spośród grona profesorskiego Uniwersytetu Padewskiego pierwszej połowy XVI wieku szczególną estymą cieszył się wśród polskich słuchaczy Carlo Sigonio (1520-1584), którego nazywano maestro amatissimo; był uczonym wielkiej klasy, cenionym erudyta, imponował szerokimi horyzontami naukowymi, rozległym wachlarzem zainteresowań oraz niespotykaną pracowitością. Zajmując się autorami starożytnymi, wydał m.in. De arte rethorica Arystotelesa oraz Consolatio Cicerona. W badaniu włoskiej historii szczególny nacisk kładł na dzieje antyczne. Rekonstruował historię Republiki Rzymskiej, zastanawiał się nad wpływem sacrum na profanum, badał darowiznę Konstantyna, prawo rzymskie oraz italskie (De antiquo iure civium Romanorum, Venetiis 1563; De antiquo iure civium Romanorum, Italiae, Provinciarum, Bononiae 1574). Wydał, opatrzywszy krytycznym komentarzem, Roczniki konsularne (Fasti consulares, Venetiis 1556), ustalił chronologię rzymską, pokazał wartość dzieła Liwiusza, opracował historię Włoch w czasach starożytnych oraz historię cesarstwa zachodniego (Historiarum de regno Italiae, libri XV, Venetiis 1574 i Historiarum de occidentali Imperio, libri XX, Bononiae 1578), aby zająć się także historią Żydów (De republica Hebraeorum, libri VII, Francofurti 1585) ${ }^{6}$. Studia ukończył w Bolonii, od 1552 r. wykładał litterarum humaniorum w Scuola di San Marco w Wenecji, w 1560 r. przeniósł się Padwy, gdzie pozostał do 1563 r. ${ }^{7}$ Był jednym z nieprzejednanych obrońców łaciny oraz żarliwym propagatorem studiów klasycznych. Jednak ostra polemika, w którą wdał się z profesorem Francescem Robortellem, doprowadziły do trwającego przeszło dwa lata sporu naukowego, co w konsekwencji skłoniło Sigonia do opuszczenia Padwy. Pozostawił po sobie ogromny dorobek; w zbiorach Biblioteki Jagiellońskiej znajdujemy 26 jego dzieł ${ }^{8}$.

W Padwie Sigonio wykładał stosunkowo krótko (1560-1563), ale wykształcił liczne grono uczniów, wśród których znalazło się 11 Polaków, a byli to: Jan Mączyński, Mikołaj Firlej (1567-1568), Marian Leżeński (1556-1559)9 , Jan Kochanowski, Andrzej Patrycy

\footnotetext{
${ }^{6}$ M. Malicki, Catalogus librorum saeculi XVI qui in Bibliotheca Jagellonica Cracoviensi asservantur, t. 1, Baden-Baden 2002, s. 201; L. Ćwikliński, Padwa i Polska, Warszawa 1922, s. 16, 80.

${ }^{7}$ W. McCuaig, Andrzej Patrycy Nidecki Carlo Sigonio, Onofrio Panvinio i nacja polska na uniwersytecie padewskim, „Odrodzenie i Reformacja w Polsce”, t. 32, 1987, s. 79 i n. 85, 86.

${ }^{8}$ L.M. Muratori, Vita Carli Sigonii, [w:] C. Sigonius, Opera omnia edita et inedita, vol. 1, Mediolani 1732, s. II-XX; L. Simeoni, Documenti sulla vita e la biblioteca di Carlo Sigonio, „Studi e memorie della storia e dell'Università di Bologna", t. 11, 1933, s. 183-262.

${ }^{9}$ Acta graduum academicorum Gymnasii Patavini ab anno 1551 ad annum 1565, a cura di E. Dalla Francesca e E. Veronese, t. 4, parte 1, Roma-Padova 2001, nr 573, 559, 626, 854, 871; St. Windakiewicz, Padwa. Studyum z dziejów cywilizacji polskiej, „Przegląd Polski”, R. 25, t. 3, 1891, s. 14; J. Ślaski, Marian Leżénski-padewczyk zapomniany, „Odrodzenie i Reformacja w Polsce”, t. 48, 2004, s. 70-86; K. Estreicher, Bibliografia polska, t. 28,
} 
Nidecki (1553-1554 oraz 1557-1559), który udał się do Sigonia aż do Wenecji, wykładającego w latach 1552-1560 w Scuola di San Marco. Uczniami Sigonia byli: Jakub Górski (1563-1564), profesor i rektor Akademii Krakowskiej oraz Jan Zamoyski, który pobierał ponoć u niego lekcje prywatne ${ }^{10}$. Jego wykładów słuchali: Jan Orzelski (1568) kronikarz, Stanisław Tarnowski (1561), Maciej Stryjkowski (1568), Jan Łasicki (1560) ${ }^{11}$. Zaprzyjaźnionym z Sigoniusem Nideckiemu i Leżeńskiemu udało się w 1558 r. dotrzeć do Wenecji, aby skłonić Senat do przeniesienia go do Padwy. W liście dedykacyjnym zamieszczonym w opublikowanych w 1559 r. Fragmenta Ciceronis Sigonio dziękował Marianowi Leżeńskiemu oraz Andrzejowi Patrycemu Nideckiemu, dając dowód bliskich z nimi kontaktów. U młodych Polaków mistrz padewski dostrzegł gorliwość w studiach, znajomość świata antycznego oraz żądzę wiedzy. Polacy odwzajemniali życzliwość do maestro amatissimo i professore polacco. W obronie Sigonia do Wenecji jeździł m.in. ówczesny konsyliarz nacji polskiej Jan Zamoyski, aby wynegocjować u władz weneckich przyznanie mu dogodniejszych godzin wykładów. W 1563 r. Jan Zamoyski, już jako rektor artystów Uniwersytetu Padewskiego, wyjednał dla swego mistrza katedrę retoryki. Jednak ten, zmęczony naukowym sporem z uniwersyteckim kolegą Francescem Robortellem, przeniósł się w 1563 r. na Uniwersytet Boloński ${ }^{12}$. Zamoyski, pamiętając o swym starym mistrzu, pod auspicjami którego pisał De senatu Romano w 1563 r., już po powrocie do ojczyzny zapraszał go do Polski w 1577 r., proponując podjęcie wykładów na nowym, planowanym uniwersytecie ${ }^{13}$.

Kraków 1930, s. 87. Carlo Sigonio dzieło pt.: De binis comitiis et lege curiata posterior cum Nicolao Gruchio disputatio dedykował Mikołajowi Firlejowi z Dąbrowicy, synowi Jana wojewody lubelskiego, który w 1566 r. słuchał jego wykładów w Bolonii o starożytnościach rzymskich; idem, Bibliografia polska, t. 14, Kraków 1896, s. 252: Fragmenta Ciceronis variis in locis dispersa, Caroli Sigonii diligentia collectta, Venetiis 1559 ex officina Stellae Jordani Zileti, dedykował Mariano Lezentio patricio polono natomiast (idem, Bibliografia polska, t. 14, s. 249) w dziele M. Tullii Ciceronis, Consolatio vel De lucta minuendo. Fragmenta eius a Carolo Sigonio et Andrea Patritio exposita. Antonij Riccoboni iudicium, quo illam Ciceronis non esse ostendit. Caroli Sigonii pro eadem orationes II, Lugduni apud Ant. Gryphium 1584, z którego wnioskujemy o współpracy dwóch uczonych padewskich z Polakiem oraz www.internetculturale.it strona oglądana 20.05.2017.

${ }^{10}$ G. Maver, I Polacchi all'Università di Padova, [w:] Il nono cinquantenario della nascità di Niccolò Copernico, Roma 1923, s. 60; St. Windakiewicz, Padwa, s. 59; St. Kot, Polska złotego wieku a Europa. Studia i szkice, Warszawa 1987, s. 228-229; H. Barycz, Historia Uniwersytetu Jagiellońskiego w epoce humanizmu, Kraków 1935, s. 366.

${ }^{11}$ J. Ślaski, Marian Leżeński, s. 82-84; W dziele Disputationum Patavinarum adversus Franciscum Robortellum, lib. 1-2, Patavini, apud Gratiosum Perchacinum 1562 zamieścił C. Sigonio dedykację dla Stanisława Tarnowskiego (M. Malicki, Catalogus librorum saeculi XVI, t. 7, Baden-Baden 2005, s. 10), zaś w pracy pt. De binis comitiis et lege curiata (ed. Bononiae 1566) wspomniał we wstępie o Mikołaju Firleju (St. Windakiewicz, Padwa, s. 59).

${ }^{12}$ M. Chachaj, Studia zagraniczne Jana Zamoyskiego (fakty, domysty, nieporozumienia), „Czasy Nowożytne”, t. 26, 2013, s. 45, 49-50; J. Ślaski, Marian Leżeński, s. 83; L. Ćwikliński, Padwa i Polska, s. 81; Archiwum Jana Zamoyskiego, t. I, nr 9, s. 398.

${ }^{13}$ Archiwum Jana Zamoyskiego, t. I, nr 158; B. Biliński, Tradizioni italiane all'Università Jagellonica di Cracovia, Wrocław-Warszawa-Kraków 1967, s. 93-94; W. McCuaig, Andrzej Patrycy Nidecki, s. 85-86; St. Kot, Polska złotego wieku, s. 312; idem, Venezia, s. 18. W XVI wieku Polacy wybierali czterokrotnie rektorów na Uniwersytecie Padewskim, pierwszym z nich był na wydziale artystów w roku 1507/1508 Andrzej de Polonia, następnym na wydziale prawa w 1525/1526 Stanisław Przeborowski i także na wydziale prawa Jan Zamoyski w 1563/1564, rektorami artystów byli: w 1566/1567. Andrzej Gostyński (Acta graduum academicorum Gymnasii Patavini ab anno 1566 ad annum 1600 (1566-1575)), a cura di E. Martellozzo Forin, t. 4, parte 2, Roma-Padova 2008, nr 101, s. XXII; oraz w 1594/1595 Jerzy Pipan (S. Windakiewicz, Padwa, s. 87, 89, 92; idem, Materiały do historyi Polaków w Padwie, „Archiwum do dziejów literatury i oświaty w Polsce”, t. 7, 1891, s. 7; K. i St. Estreicher, Bibliografia polska, t. 35, Kraków 2000, s. 336-337: De Senatu Romano, Venetiis apud Jor- 
W Bibliotece Jagiellońskiej znajduje się 26 tytułów dzieł Carla Sigonia w 32 egzemplarzach. Aż 12 z nich należało do biskupa Piotra Dunin-Wolskiego (1531-1590). Ten wybitny humanista, podkanclerzy, kanclerz wielki koronny, dyplomata, kanonik gnieźnieński, płocki, poznański, krakowski, biskup przemyski, a następnie płocki był także bibliofilem i właścicielem cennej biblioteki gromadzonej w Pułtusku. Wolski studiował początkowo w Akademii Lubrańskiego w Poznaniu, następnie we Włoszech, w Bolonii i Padwie, gdzie jako Petrus Wolsens f. d. Pauli wystąpił w 1549 r. w charakterze świadka przy nadaniu stopnia doktora medycyny Marcinowi Próchnickiemu(? $)^{14}$. Z tej przyczyny nie dziwią jego szerokie zainteresowania intelektualne, przekładające się na tematykę dzieł gromadzonych do końca życia ${ }^{15}$. Lata 1561-1573 spędził w Hiszpanii w związku z egzekucją praw Zygmunta Augusta do spadku po matce, zagarniętego przez Filipa II (tzw. sumy neapolitańskie). W latach 1579-1582 przebywał w Rzymie, na dworze papieskim, gdzie czuwał nad polskimi sprawami. Wracając z poselstwa u Grzegorza XIII, zatrzymał się w grudniu 1582 r. w Bolonii, gdzie pozostał do końca kwietnia. Wówczas zwiedził muzeum i bibliotekę sławnego lekarza i botanika, Ulissesa Aldrovandiego. Wśród Polaków cieszył się opinią najlepiej władającego językiem włoskim. Piotr Dunin-Wolski zmarł w Pułtusku w 1590 r. ${ }^{16} \mathrm{Na}$ mocy testamentu podzielił swój cenny księgozbiór między Akademię Krakowską a kapitułę katedralną w Płocku. Do Krakowa księgi trafiły w półroczu letnim 1592 r., przewiezione przez magistra Wacława Baseniusza ${ }^{17}$.

Z dzieł Carla Sigonia w zbiorze Wolskiego tematyki historycznej dotyczy 9 tomów. Są to prace z zakresu historii starożytnej, które omawiają zarówno dzieje Grecji, określane jako czasy Ateńczyków i Spartan, jak i Rzymu. W dwóch dziełach obejmujących okres cesarstwa rzymskiego: Historiarvm de occidental Imperio libri XX .. ${ }^{18}$ oraz Historiarvm de regno Italiae Libri Quindecim ... ${ }^{19}$ znajdują się notatki Jana Brożka (1585-1652) ${ }^{20}$. Ten sławny matematyk i astrolog, doktor medycyny (1623 r. w Padwie) i teologii (1629 r.), profesor i rektor Akademii Krakowskiej, miał zwyczaj komentowania oraz zaznaczania

danum Ziletum 1563, dzieło Zamoyskiego, w którym udowodnił znajomość Liwiusza i Cicerona, było pisane pod opieką padewskich profesorów, a przede wszystkim Carla Sigonia. Umieścił w nim list Senatu Weneckiego, który zalecał go królowi Zygmuntowi Augustowi; S. Łempicki, Działalność Jana Zamoyskiego na polu szkolnictwa 1573-1605, Kraków 1921, s. 29, 35, 37.

${ }^{14}$ Acta graduum academicorum Gymnasii Patavini ab anno 1538 ad annum 1550, a cura di E. Martellozzo Forin, t. III, parte 3, Padova 1971, nr 3921; A. Obrębski, Dziennik z lat 1561-1583 dyplomaty i biskupa plockiego Piotra Dunin-Wolskiego, „Biuletyn Biblioteki Jagiellońskiej”, R. 42, 1992, s. 101-103; J. Nowacki, Dzieje archidiecezji poznańskiej, t. 2, Archidiecezja poznańska w granicach historycznych i jej ustrój, Poznań 1964, s. 96.

${ }_{15}$ Volsciana. Katalog renesansowego księgozbioru Piotra Dunin-Wolskiego, biskupa płockiego, oprac. Andrzej Obrębski, Kraków 1999, s. 5.

${ }^{16}$ Volsciana, s. 5; H. Barycz, Polacy na studiach w Rzymie w epoce Odrodzenia (1440-1600). Kraków 1938, s. 185, 203, 234, 256; S. Windakiewicz, Padwa, s. 27; D. Quirini-Popławska, I visitatori Polacchi del museo di oggetti naturali di Ulisses Aldrovandi, [w:] Commentationes historicae, Warszawa-Kraków 1988, s. 161-162; A. Obrębski, Dziennik z lat 1561-1583, s. 126.

${ }^{17}$ Volsciana, s. 7.

${ }^{18}$ Caroli Sigonii Historiarvm de occidental Imperio libri XX. Ad ... Iacobum Boncompagnum, Bononiae, Apud Societatem Typographiae Bononiensis, MDLXXVIII (BJ St. Dr. 393451 III).

${ }^{19}$ Caroli Sigonii Historiarvm de regno Italiae Libri Quindecim. Ad ... Iacobum Boncompagnum ... Qui libri Historiam ab anno DLXX vsque ad MCC continent, Venetiis, Apud Iordanem Zilettum, MDLXXIIII (BJ St. Dr. 393397 III). Opisy dzieł sporządzono wedle zasad przyjętych w Catalogus librorum saeculi XVI qui in Bibliotheca Jagellonica Cracoviensis asservantur, t. III-V, curavit M. Malicki, Baden-Baden 2003-2007.

${ }^{20}$ A. Birkenmajer, Brożek (Broscius) Jan, [w:] Polski Słownik Biograficzny (dalej PSB), t. 3, Kraków 1937, s. 1. 
istotnych dla niego ustępów w czytanym tomie, dzięki czemu można rozpoznać dzieła, które leżały w kręgu jego szerokich zainteresowań ${ }^{21}$.

Ciekawą pracą w zbiorze Wolskiego jest rozprawa C. Sigonia, omawiająca rzadko poruszaną przez ówczesnych badaczy historię narodu żydowskiego De Rep. Hebraeorvm libri VII Ad Gregorivm XIII Pontificem Maximvm... ${ }^{22}$. Pozostałe opracowania padewskiego profesora zgromadzone przez płockiego biskupa dotyczyły różnorodnych zagadnień, w tym tak istotnych, jak konieczność stosowania łaciny, pochwała historii czy studiów nad kultura, np. Orationes septem. Pro eloquentia. IIII. De vsv linguae Latinae retinendo... Do księgozbioru Wolskiego należało także wydanie Arystotelesa z 1565 r. De Arte rhetorica..., zawierające interpretacje Carla Sigonia ${ }^{23}$.

Właścicielem De antiqvo ivre civivm Romanorvm libri dvo... w $1563 \mathrm{r}^{24}$ był Stanisław Mareniusz-Twardy (ok. 1532-1580), filolog i teolog, profesor Akademii Krakowskiej, kustosz fundacji Benedykta z Koźmina ${ }^{25}$. Ten wychowanek Stanisława Grzepskiego, znawca łaciny, greki, języka hebrajskiego, właściciel jednego z najcenniejszych księgozbiorów humanistycznych i filologicznych II poł. XVI w., zapisał swój zbiór bibliotekom Collegium Maius i Collegium Minus ${ }^{26}$. W księgozbiorze Mareniusza znajdowała się praca zbiorowa dotycząca historii Rzymu, w której C. Sigonio był jednym z współautorów ${ }^{27}$. (Il. 1).

Proweniencja dzieła o dawnym prawie rzymskich, o państwie ateńskim i o państwie żydowskim De antiqvo ivre civivm Romanorvm, Italiae, provinciarvm, ac Romanae ivrisprvdentiae ivdiciis ... jest bardziej złożona ${ }^{28}$. Pierwszym potwierdzonym właścicielem był

\footnotetext{
${ }^{21}$ Archiwum nacji polskiej $w$ Uniwersytecie Padewskim, t. I. Metryka nacji polskiej w Uniwersytecie Padewskim (1592-1745), do druku przyg. H. Barycz, indeks K. Targosz, Wrocław-Warszawa-Kraków-Gdańsk 1971, s. 286; L. Rossetti, Dottorati Polacchi a Padova dal 1600 al 1744 nel Sacro Collegio dei filosofi e medici di Padova (dall'Archivio Antico dell'Università), [w:] Relazioni tra Padova e la Polonia, Padova, 1964, nr 47, s. 151.

${ }^{22}$ Caroli Sigonii De Rep. Hebraeorvm libri VII Ad Gregorivm XIII Pontificem Maximvm, Bononiae, Apud Ioannem Rossium, MDLXXXII (BJ St. Dr. 590186 I oraz BJ St. Dr. 593435 II).

${ }^{23}$ Aristotelis De Arte rhetorica libri tres. Carolo Sigonio interprete, Bononiae, Ex Officina Alexandri Benatti, MDLXV (BJ St. Dr. 593341 II); K. Estreicher, Bibliografia polska, t. 12, Kraków 1891, s. 211 w wydaniu tegoż dzieła Cracoviae ex officina Stanislai Schaeffenbergi 1577 znajduje się dedykacja skierowana do Łukasza Podoskiego, proboszcza gnieźnieńskiego i kanonika krakowskiego.

${ }^{24}$ Caroli Sigonii De antiqvo ivre civivm Romanorvm libri dvo. Eivsdem De antiqvo ivre Italiae libri tres. Ab ipso auctore multis in locis aucti..., Venetiis, ex officina Iordani Zileti, MDLXIII (BJ St. Dr. Cim. 5910).

${ }^{25}$ L. Hajdukiewicz, Mareniusz (Marennius) Stanisław, [w:] PSB, t. 19, Wrocław-Warszawa-Kraków-Gdańsk 1974, s. 631; W. Urban, Akademia Krakowska w dobie reformacji i wczesnej kontrreformacji (1549-1632), [w:] Dzieje Uniwersytetu Jagiellońskiego w latach 1364-1764, t. I, red. K. Lepszy, Kraków 1964, s. 289.

${ }^{26}$ W. Urban, Akademia Krakowska, s. 289; A. Lewicka-Kamińska, Biblioteka Jagiellońska w latach 14921655, [w:] Historia Biblioteki Jagiellońskiej, t. 1, 1364-1775, pod red. I. Zarębskiego, Kraków 1966, s. 266; L. Hajdukiewicz, Mareniusz, s. 632; H. Barycz, Z epoki renesansu, reformacji i baroku: prady - idee - ludzie ksiażki, Warszawa 1971, s. 578; Historia nauki polskiej, pod red. B. Suchodolskiego, t. 6, Dokumentacja biobibliograficzna, oprac. L. Hajdukiewicz, Indeks biograficzny tomu 1 i 2, Wrocław [et al.] 1974, s. $402-403$.

${ }^{27}$ Varii historiae Romanae scriptores, partim Graeci, partim Latini, in vnvm velut corpus redacti, De rebus..., Anno M.D.LXVIII excudebat Henricus Stephanus (BJ St. Dr. 590165 I).

${ }^{28}$ Caroli Sigonii De antiqvo ivre civivm Romanorvm, Italiae, provinciarvm, ac Romanae ivrisprvdentiae ivdiciis, Libri XI. Eivsdem, De Republica Atheniensium, eorumque ac Lacedaemoniorum temporibus libri quinque. Quibus adiecti sunt eiusdem de Republica Hebraeorum, libri septem: Et In B. Sulpicij Seueri historicos libros duos, Commentarij duo. Addita... anacephalaeosi chronologica historiarum Sulpicianarum, Francofvrti, Apud heredes Andreae Wecheli, Claudium Marnium, \& Ioan. Aubrium. M.D.XCIII (BJ St. Dr. Prawo 16619).
} 
bliżej nieznany Okolski ${ }^{29}$. Następnym dysponentem tego dzieła był magister artium Daniel Otrębosz, bakałarz w 1626 r., doktor filozofii, profesor Szkół Nowodworskich ${ }^{30}$. Zanim tom ten trafił do uniwersyteckiej biblioteki, jego posiadaczem był Łukasz Piotrowski (zm. w 1679) ${ }^{31}$, doktor filozofii, profesor Akademii Krakowskiej, autor podstawowego w tym czasie akademickiego podręcznika do gramatyki. Był on właścicielem cennego filologicznego księgozbioru, który trafił po jego śmierci do biblioteki Collegium Maius ${ }^{32}$. W zbiorze tym znaleźć można było pracę klasyka rzymskiej historiografii Liwiusza Historiarum ab urbe condita, libri ... z komentarzami Sigonia ${ }^{33}$.

Dzieło C. Sigonia o historii cesarstwa zachodniego Historiarvm de occidentali Imperio libri $X X$..., wydane we Frankfurcie w $1593 \mathrm{r}^{34}$ i przechowywane w Bibliotece Jagiellońskiej, jest współoprawne z drugą księga jego autorstwa, Historiarvm de regno Italiae Libri Viginti... ${ }^{35}$ Ten klocek introligatorski należał do profesora Akademii Krakowskiej, Szymona Halicjusza (Kociołka) z Pilzna (1576-1625), kanonika krakowskiego, kierownika katedry wymowy, założonej w 1615 r. przez biskupa Piotra Tylickiego. Jego księgozbiór po śmierci został przekazany do Collegium Maius ${ }^{36}$. Niemniej omawiany tom chory i przybity do łoża Halicjusz podarował profesorowi wymowy, aby wyjść naprzeciw tym, którzy chcq zdobyć umiejętność elokwencji, w dniu św. Zygmunta w 1623 r. Kolejnym właścicielem był wspomniany już wyżej Łukasz Piotrowski. Po jego śmierci egzemplarz ten nie trafił jednak tak jak cały księgozbiór do biblioteki Collegium Maius, lecz do biblioteki Collegium Minus.

Drugi egzemplarz Historiarvm de occidentali Imperio libri XX ... z $1593 \mathrm{r}^{37}$ należał do Adama z Opatowa (1574-1647), doktora filozofii w 1598 r., studenta Uniwersytetu Padewskiego w 1618 r., doktora teologii promowanego w Rzymie w 1619 r., profesora i siedmiokrotnego rektora Akademii Krakowskiej, kanonika krakowskiego, kustosza (1612-1624)

${ }^{29}$ Katalog poloników XVI wieku Biblioteki Jagiellońskiej, pod red. M. Malickiego i E. Zwinogrodzkiej, t. 3, Indeksy, Kraków 1995, s. 291.

${ }^{30}$ Katalog poloników XVI wieku Biblioteki Jagiellońskiej, s. 292.

${ }^{31}$ M. Michalewiczowa, Piotrowski Łukasz h. Junosza, [w:] PSB, t. 26, Wrocław-Warszawa-Kraków-GdańskŁódź 1981, s. 489.

${ }^{32}$ A. Przyboś, Akademia Krakowska w drugiej połowie w. XVII, [w:] Dzieje Uniwersytetu Jagiellońskiego w latach 1364-1764, t. 1, Kraków, 1964, s. 399; H. Barycz, Historia szkól nowodworskich od założenia do reformy H. Koltataja (1588-1777), Kraków 1988, s. 172-173; M. Michalewiczowa, Piotrowski, s. 489; Historia nauki polskiej, t. 6, s. 518.

${ }^{33}$ T. Livii... Historiarum ab vrbe condita, libri, qvi extant, XXXV. Cvm universae Historiae epitomis.Adiunctis Scholijs Caroli Sigonii..., Venetiis, Apvd Paulum Manutium, Aldi F. MDLXVI (BJ St. Dr. Latina 2726).

${ }^{34}$ Caroli Sigonii Historiarvm de occidental Imperio libri XX. Ad... Iacobum Boncompagnvm ... Pertexitur autem in illis historia ab anno... CCLXXXIIII, vsque ad annum DLXV, Francofvrti Apud heredes Andreae Wecheli, Claudium Marnium \& Ioann. Aubrium, MDXCIII (BJ St. Dr. Prawo 16959).

${ }^{35}$ Caroli Sigonii Historiarvm de regno Italiae Libri Viginti. Ad... Iacobvm Boncompagnvm ... Qui libri Historiam ab anno DLXX vsque ad MCCLXXXVI... continent. ([Pars 2]: Historiarvm de regno Italiae Quinque reliqui Libri... qui libri nunc primum editi), Francofvrti Apud heredes Andreae Wecheli, Claudium Marnium \& Ioann. Aubrium, MDXCI) (BJ St. Dr. Prawo 16960).

${ }^{36}$ L. Hajdukiewicz, Halicjusz Szymon, [w:] PSB, t. 9, Wrocław-Kraków-Warszawa 1960-1961, s. 247; W. Urban, Akademia Krakowska, s. 294; A. Lewicka-Kamińska, Biblioteka Jagiellońska, s. 266; Historia nauki polskiej, t. 6, s. 213; H. Barycz, Historia Uniwersytetu Jagiellońskiego, s. 525-526, 608.

${ }^{37}$ Caroli Sigonii Historiarvm de occidentali Imperio libri XX. Ad... Iacobum Boncompagnvm ... Pertexitur autem in illis historia ab anno... CCLXXXIIII, vsque ad annum DLXV, Francofvrti Apud heredes Andreae Wecheli, Claudium Marnium \& Ioann. Aubrium, MDXCIII (BJ St. Dr. 379883 III). 
i prowizora (1638-1646) biblioteki Collegium Maius ${ }^{38}$. Ten teolog, znawca greki, wywodzący się z zamożnej rodziny mieszczańskiej ${ }^{39}$, w latach 1604-1606 kształcił Jakuba Sobieskiego, ojca Jana III Sobieskiego ${ }^{40}$. W 1646 r. ofiarował 4.150 zł dla studentów z Opatowa ${ }^{41}$. Jego księgozbiór, który zgodnie $\mathrm{z}$ uniwersytecką tradycją trafił po jego śmierci w 1647 r. do biblioteki Collegium Maius, poza dziełami teologicznymi obejmował liczny zbiór autorów klasycznych: Diogenesa, Laertiosa, Plutarcha, Seneki, Liwiusza (w wydaniach pierwszorzędnych drukarzy: H. Etienne z Genewy, S. Feyerabenda z Frankfurtu i Platyna z Antwerpii) ${ }^{42}$. Jedno z tych wydawnictw, T. Livii... Libri omnes, qvotqvot ad nos pervenere...$^{43}$, zawiera uwagi F. Robortella i C. Sigonia oraz dodatkowo nową chronologię rzymskich dziejów autorstwa tego ostatniego.

Kanonik krakowski, profesor i rektor Akademii Krakowskiej, Andrzej Kucharski (ok. 1608-1679) ${ }^{44}$ był, po Macieju S. Drohojewskim (wpis z 1617 r.), drugim potwierdzonym posiadaczem innego egzemplarza Historiarvm de regno Italiae Libri Viginti ... ${ }^{45}$ Kucharski był doktorem obojga praw, tytuł doktora teologii uzyskał w rzymskiej Sapienzy w 1657 r., nostryfikowany w Krakowie na początku roku $1658^{46}$. Został kanonikiem krakowskim w 1661 r. oraz rektorem Akademii. Od 1654 r. jako bibliotekarz Collegium, uporządkował i zreformował tamtejszą bibliotekę ${ }^{47}$, gdzie trafił po śmierci jego księgozbiór, w którym znaleźć można, obok dzieł teologicznych, także księgi medyczne oraz klasyczne pozycje: Ksenofonta, Demostenesa, Tukidydesa, Lukiana i Dionizjusza Kasjusza. Co niezwykle istotne, były to głównie wydania nowych opracowann ${ }^{48}$.

Drugim wybitnym profesorem Uniwersytetu Padewskiego był wspomniany już wyżej Francesco Robortello (1516-1567) z Udine. Należąc do grona wybitnych filologów, cieszył się sławą świetnego znawcy starożytności, hellenisty, był też propagatorem stosowania języka narodowego w nauce. W Padwie wykładał od 1557 r., zaś w 1561 r. otrzymał katedrę filozofii moralnej. Był doświadczonym edytorem oraz autorem pionierskiej pracy nad tekstami Arystotelesa z komentarzem: Etyki, Ekonomii i Polityki. Był przedstawicielem humanizmu uczonego, wskrzesicielem filologii klasycznej, a wydając Ajschylosa Tragedie

${ }^{38}$ A. Lewicka-Kamińska, Biblioteka Jagiellońska, s. 218-219, 222-223; Archiwum nacji polskiej w Uniwersytecie Padewskim, t. I, s. 345, nr 808; W. Urban, Akademia Krakowska, s. 273, 291; Poczet rektorów Uniwersytetu Jagiellońskiego 1440-2000, Kraków 2000, s. 173.

${ }^{39}$ W. Urban, Akademia Krakowska, s. 291.

${ }^{40}$ A. Przyboś, Akademia Krakowska $w$ drugiej połowie w. XVII, s. 328.

${ }^{41}$ Ibidem, s. 344.

${ }^{42}$ A. Lewicka-Kamińska, Biblioteka Jagiellońska, s. 168.

${ }^{43}$ T. Livii... Libri omnes, qvotqvot ad nos persvenere; Nove editi, et recogniti, et ad..., T. 1-2, Francofurti impensis Sigism. Feyrabendii \& Sociorum, 1588 (BJ St. Dr. Latina 2730).

${ }^{44}$ L. Hajdukiewicz, Kucharski Andrzej, [w:] PSB, t. XXVI, Wrocław-Warszawa-Kraków-Gdańsk-Lódź 1981, s. 45; Historia nauki polskiej, t. 6, s. 339; A. Lewicka-Kamińska, Biblioteka Jagiellońska, s. 302.

${ }^{45}$ Caroli Sigonii Historiarvm de regno Italiae Libri Viginti. Ad ... Iacobvm Boncompagnvm ... Qui libri Historiam ab anno DLXX vsque ad MCCLXXXVI... continent. ([Pars 2]: Historiarvm de regno Italiae Quinque reliqui Libri... qui libri nunc primum editi.), Francofvrti Apud heredes Andreae Wecheli, Claudium Marnium \& Ioann. Aubrium, MDXCI (BJ St. Dr. 940400 III).

${ }^{46}$ L. Hajdukiewicz, Kucharski, s. 45; Historia nauki polskiej, t. 6, s. 339; Poczet rektorów, s. 193.

${ }^{47}$ A. Lewicka-Kamińska, Biblioteka Jagiellońska, s. 222, 291, 301 i 303; H. Barycz, Historia Uniwersytetu Jagiellońskiego, s. 686; L. Łętowski, Katalog biskupów, prałatów i kanoników krakowskich, t. 3, Kraków 1852, s. 211.

${ }^{48}$ A. Lewicka-Kamińska, Biblioteka Jagiellońska, s. 343 i 352. 
oraz Pisma Longinusa z Kapadocji (I w. n.e.), zapewnił sobie pamięć potomnych ${ }^{49}$. Wśród jego dzieł wymienić trzeba: In librum Aristotelis de arte poetica explicationes 1548; De rhetorica facultate 1548; De arte sive ratione corrigendi veteres authores disputatio, Patavii 1557; De historica facultate disputatio, Florentiae 1567; De artificio dicendi, Bononiae 1567. Był nie tylko ulubionym profesorem studentów niemieckich, także mistrzem wielu Polaków.

Do jego uczniów należeli m.in. Andrzej Patrycy Nidecki w latach 1552-1557 (Nidecki gościł w Padwie dwukrotnie - w latach 1553-1556, 1557-1559) oraz późniejszy kanonik krakowski, sekretarz królewski i dyplomata Łukasz Podoski (w Padwie przebywał w latach 1555-1558). We wstępie do dzieła Marcina Kromera De origine et rebus, Francesco Robortello wspomina go, pisząc: Lucas Podoscius auditor meus, iuvenis propter singularem vistutem et eruditionem mihi charissimus, przywołuje również Patrycego Nideckiego ${ }^{50}$. W Padwie oprócz naszego największego poety renesansowego, Jana Kochanowskiego studiowali: Maciej Stryjkowski, Franciszek Masłowski (1557), Paweł Stempowski (15531554), Stanisław Warszewicki (1554), Stanisław Grodzicki (1557, późniejszy biskup ołomuniecki) Stanisław Iłowski (1561), prawdopodobnie też Wawrzyniec Goślicki ${ }^{51}$. Nie wiadomo, w jakich okolicznościach poznał sławnego profesora kronikarz i wytrawny dyplomata, Marcin Kromer. Niemniej zamieszczenie przez Kromera w swoim dziele De origine et rebus gestis Polonorum libri XXX, drukowanym w 1568 r. (Basileae ex officina Oporiniana), wstępu w formie listu Robortella jest potwierdzeniem tego faktu ${ }^{52}$.

W Bibliotece Jagiellońskiej znajduje się dziewięć dzieł Francesca Robortella. Księga dotycząca chronologii Liwiusza De convenientia svppvtationis Livianae ... ${ }^{53}$, zanim trafiła do Akademii Krakowskiej, wpierw należała do biskupa Piotra Wolskiego, a następnie do Grzegorza Golińskiego (1593-1631), profesora wymowy. Po jego zgonie wraz z cenną biblioteką filologiczną trafiła do Collegium Maioris ${ }^{54}$. (Il. 2).

W księgozbiorze Wolskiego znajdowało się także inne dzieło F. Robortella, przedstawiające dzieje rzymskie za cesarza Augusta De vita, et victv Popvli Romani svb Impp. Caess. Avgg.... ${ }^{55}$

\footnotetext{
${ }^{49}$ Fr. Dupuigrenet Desroussilles, L'università di Padova dal 1405 al Concilio di Trento, [w:] Storia della culura veneta, t. 2, Vicenza 1980, s. 641; L. Ćwikliński, Padwa i Polska, s. 13, 22.

${ }^{50}$ Marcin Kromer, De origine et rebus gestis Polonorum, Basilea 1568 , f. 5r, 5v; S. Windakiewicz, Padwa, s. 26.

${ }^{51}$ J. Ślaski, Marian Leżeński, s. 81; St. Windakiewicz, Padwa, s. 23, 77, 82; S. Bednarski, Stanisława Warszewickiego pochodzenie, młodość, studia w Wittenberdze i Padwie, [w:] Studia z dziejów kultury, red. H. Barycz i J. Hulewicz, Warszawa 1949, s. 255.

${ }^{52} \mathrm{Na}$ stronie tytułowej dzieła Marcina Kromera De origine et rebus gestis Polonorum umieszczony został zapis: Accessit iudicium Franciscii Robortelli Utinensis, de authore eiusdem libro, zaś na stronach 5r i 5v opublikowany został wstęp pt. Franciscus Robortellus Utinensis Martino Cromero SD, (BJ. St.Dr. Cim. 8488-8490); I. Chrzanowski, S. Kot, Humanizm i reformacja w Polsce, Lwów 1927, s. 193-194.

${ }^{53}$ Francisci Robortelli... De convenientia svppvtationis Livianae Ann. cvm marmoribvs Rom. quae in Capitolio svnt. Eivsdem De arte, sive Ratione corrigendi veteres Authores, disputatio. Eivsdem emendationvm libri dvo, Patavii, Apud Innocentium Olmum. (... Excudebat Gratiosus Perchacinus ...), MDLVII (BJ St. Dr. 393380 III).

${ }^{54}$ A. Lewicka-Kamińska, Biblioteka Jagiellońska, s. 167, 171; L. Hajdukiewicz, Goliński Grzegorz, [w:] PSB, t. 8, Wrocław-Kraków-Warszawa 1959-1960, s. 225-226.

${ }^{55}$ Francisci Robortelli... De vita, et victv Popvli Romani svb Impp. Caess. Avgg. Tomus primus, qvi continet libros XV. Ad... Io. Baptistam Campegium... Eiusdem Disputationes nouem. De prouinciarum administratione, $\&$ distributione apud Romanos. De iudiciis Romanorum. De legibus Romanorum. De magistratibus imperatorum Rom. De familiis Romanorum. De cognominibus Imperatorum Romanorum, \& appellationibus. De commodis, \& praemiis, ac donis militaribus. De poenis, \& ignominiis militum Rom. De gradibus honorum, Bononiae, Ex Typographia Io. Bapt. \& Alexandri Benaciorum, \& Ioannis Rubei sociorum, 1559 (BJ St. Dr. 393481 III).
} 
oraz praca De republica recte administranda atqve aliis ad ..., którą Robortello przygotował do druku ${ }^{56}$.

Pierwszym potwierdzonym właścicielem pracy De historica facultate, discputatio eiusdem Laconici, seu sudationis explicatio eiusdem ... ${ }^{57}$ był profesor i rektor krakowskiej Akademii, prowizor fundacji Benedykta z Koźmina, kanonik krakowski, Bazyli (Błażej)

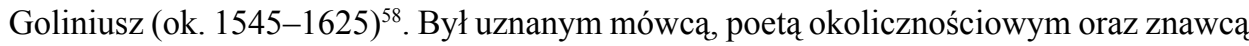
trzech języków antycznych (homo trilinguis). Część ksiąg zawędrowała po jego śmierci do katedry grecystyki, część przekazał swoim przyjaciołom ${ }^{59}$. Jednym z nich był grecysta, profesor Akademii Krakowskiej, dziekan wydziału filozoficznego, Adam Draski (zm. 1648) ${ }^{60}$. W 1626 r. objął po Starnigelu katedrę grecystyki, przyczynił się też do powstania sporej biblioteki grecystycznej ${ }^{61}$. Jeszcze zanim objął katedrę grecystyki, trafiła do niego po Goliniuszu Bibliothecae historicae libri $X V$... Diodora Siculusa ${ }^{62}$. W księgozbiorze Draskiego znajdowała się inna księga zawierająca pracę F. Robortella - dzieło Demetriusa Phalereusa De elocvtione liber, à Stanislao Ilovio Polono Latinitate donatus, \& annotationibus illustratus. Item... ${ }^{63}$. Z wpisu wynika, że także to dzieło Draski dostał od kolegi-grecysty: M[agister] Adamij Hyacintij Draskij collega pro usu profesoris gaeci dedit.

Marcin Gilewski (zm. 1630 ${ }^{64}$, który był egzekutorem testamentu Goliniusza, przekazał dzieło F. Robortella De historica facultate, discputatio Eiusdem Laconici... (BJ St. Dr. Neolatina 426 II) profesorowi języka hebrajskiego. Przypuszczalnie chodzi w tym zapisie o rektora uniwersytetu, profesora wymowy, Jakuba Witeliusza $(1587-1648)^{65}$, którego wpis znajduje się na karcie tytułowej. Studiował on na Uniwersytecie Padewskim w 1638 r., i w tym też roku uzyskał w Rzymie doktorat z zakresu teologii; był znawcą trzech języków, vir trilinguis, kierownikiem katedry wymowy, założonej w 1615 r. przez biskupa Piotra Tylickiego, i przyjacielem przywołanego wcześniej Jana Brożka ${ }^{66}$. Witeliusz piastował godność kanonika krakowskiego oraz kustosza i prowizora biblioteki Collegium Maioris. Tam też trafiła po jego śmierci część księgozbioru obejmująca dzieła teologiczne oraz

\footnotetext{
${ }^{56}$ De repvblica recte administranda atqve aliis ad moralem disciplinam pertinentibus rebus..., [Ed.:] Francesco Robortello, Venetiis, [Francesco Portonari], MDLXXVIII (BJ St. Dr. 593381 II).

${ }^{57}$ Francisci Robortelli... De historica facultate, disputatio Eiusdem Laconici, seu sudationis explicatio Eiusdem De Nominibus Romanorum Eiusdem De Rhetorica facultate Eiusdem Explicatio in Catulli epithalamium His accesservnt eivsdem Annotationum in uaria tam Graecorum, quam Latinorum loca Libri II. Ode Graeca quae Biochresmodia inscibitur Explanationes in primum Aeneid. Vergilij librum eodem Robortello praelegente collectae a Ioanne Baptista Busdrago Lucensi, Florentiae apud Laurentium Torrentinum, Mense Iulio MDXLVIII (BJ St. Dr. Neolatina 426).

${ }^{58}$ L. Hajdukiewicz, Goliniusz Błażej Bazyli, [w:] PSB, t. 8, Wrocław-Kraków-Warszawa 1959-1960, s. 221; Historia nauki polskiej, t. 6, s. 187-188; L. Łętowski, Katalog biskupów, t. 2, Kraków 1852, s. 260.

${ }^{59}$ A. Lewicka-Kamińska, Biblioteka Jagiellońska, s. 166 i 228; Poczet rektorów, s. 167; W. Urban, Akademia Krakowska, s. 273-274, 289.

${ }^{60}$ H. Barycz, Draski Adam, [w:] PSB, t. 5, Kraków 1939-1946, s. 361; Historia nauki polskiej, t. 6, s. $133-134$.

${ }^{61}$ W. Urban, Akademia Krakowska, s. 290.

${ }^{62}$ A. Lewicka-Kamińska, Biblioteka Jagiellońska, s. 166.

${ }^{63}$ De elocvtione liber, à Stanislao Ilovio Polono Latinitate donatus, \& annotationibus illustratus. Item, Dionysii Halicarnassei quaedam opuscula... (Francisci Robortelli, De facultate historia disputatio), Basileae, per Ioannem Oporinum (M.D.LVII. Mense Martio), (BJ St. Dr. Cim. 680).

${ }^{64}$ A. Lewicka-Kamińska, Biblioteka Jagiellońska, s. 166.

${ }^{65}$ Ibidem, s. 168; Historia nauki polskiej, t. 6, s. 749-750.

${ }^{66}$ W. Urban, Akademia Krakowska, s. 294, A. Lewicka-Kamińska, Biblioteka Jagiellońska, s. 170; Archiwum nacji polskiej, t. 1, s. 410, nr 1295.
} 
książki greckie, hebrajskie i włoskie. Pozostały zbiór podzielił między bibliotekę Collegium Minus i Kolegium Nowodworskiego ${ }^{67}$. (Il. 3).

Dzieło F. Robortella o poetyce Arystotelesa i Horacego ....in librum Aristotelis De arte poetica explicationes. Qui ab eodem Authore ex manuscriptis libris, multis in locis emendatus fuit... Paraphrasis in librvm Horatii... ${ }^{68}$ zakupił w 1567 r. do biblioteki Collegium Maius Mikołaj z Bodzentyna ${ }^{69}$, późniejszy rektor (zm. 1586) ${ }^{70}$. Tom zdobi oprawa typowa dla fundacji Koźmińczyka. Benedykt z Koźmina (zm. 1559) ${ }^{71}$, profesor i podkanclerzy Akademii Krakowskiej, testamentem z 26 listopada 1559 r. zapisał kwotę 1.000 złp. na rzecz Collegium Maius. Roczny czynsz od tej kwoty, wynoszący 50 złp., przeznaczany miał być na zakup nowych książek do biblioteki, przy czym chodziło o dzieła wartościowe, naukowe, okazałe, wybite dużymi czcionkami. Oprawiano je w charakterystyczną czerwoną skórę, naciągniętą na deskę. Złoty wycisk zdobiący oprawny tom świadczy o bibliofilskich upodobaniach Koźmińczyka ${ }^{72}$. Z sum, którymi dysponowała fundacja, zakupiono także dzieło Marcina Kromera De origine et rebus gestis Polonorum libri XXX... ${ }^{73}$, do którego wstęp napisał F. Robortello.

Inne wydanie pracy Robortella ...in librum Aristotelis De arte poetica explicationes. Qui ab eodem Authore ex manuscriptis libris, multis in locis emendatus fuit ... Paraphrasis in librvm Horatii, qvi vvlgo De arte poetica ... ${ }^{74}$ było w posiadaniu Marcina Gliciusa z Pilzna (1528-1591), doktora filozofii i teologii, kanonika wrocławskiego i krakowskiego, profesora i 16-krotnego rektora Akademii Krakowskiej, a także pierwszego kuratora fundacji Benedykta z Koźmina, właściciela cennego księgozbioru ${ }^{75}$. W zbiorze tym znaleźć można było dzieła starożytnych autorów z komentarzami współczesnych filologów. Przypuszczalnie była wśród nich wspomniana już praca Robortella De historica facultate,

${ }^{67}$ A. Lewicka-Kamińska, Biblioteka Jagiellońska, s. 168-169; Poczet rektorów, s. 177.

${ }^{68}$ Francisci Robortelli... in librum Aristotelis De arte poetica explicationes. Qui ab eodem Authore ex manuscriptis libris, multis in locis emendatus fuit... [Acc.:] Francisci Robortelli... Paraphrasis in librvm Horatii, qvi vvlgo De arte poetica ad Pisones inscribitvr. Eivsdem explicationes De satyra De epigrammate De comoedia De salibvs De elegia Quae omnia addita ab authore fuerunt, ut nihil quod ad poeticam spectaret desiderari posset: Nam in iis scribendis Aristotelis methodum seruauit: \& ex ipsius Libello de arte Poetica principia sumpsit omnium suarum explicationum, Florentiae In Officina Laurentii Torrentini..., MDXLVIII, (BJ St. Dr. Greka 3591).

${ }^{69}$ A. Lewicka-Kamińska, Biblioteka Jagiellońska, s. 158 i 188.

${ }^{70}$ H. Barycz, Bodzęcin (z Bodzęcina) Mikołaj, [w:] PSB, t. 2, Kraków 1936, s. 181.

${ }^{71}$ H. Barycz, Benedykt z Koźmina, [w:] PSB, t. 1, Kraków 1935, s. 425; idem, Historia Uniwersytetu Jagiellońskiego, s. 699-708.

${ }^{72}$ A. Lewicka-Kamińska, Biblioteka Jagiellońska, s. 178-179.

${ }^{73}$ Martini Cromeri De Origine Et Rebus Gestis Polonorum Libri XXX; Adiecta est in fine, eiusdem autoris funebris Oratio Sigismundi Regis vitam compendiose complexa, \& aliquoties iam prius edita. Acceßit iudicium Francisci Robortello... de autore \& libro, Basileae, Per Ioannem Oporinum, M.D.LVIII (BJ St. Dr. Cim. 8155).

${ }^{74}$ Francisci Robortelli... in librum Aristotelis De arte poetica explicationes. Qui ab eodem Authore ex manuscriptis libris, multis in locis emendatus fuit... [Acc.:] Francisci Robortelli... Paraphrasis in librvm Horatii, qvi vvlgo De arte poetica ad Pisones inscribitvr. Eivsdem explicationes De satyra De epigrammate De comoedia De salibvs De elegia Quae omnia addita ab authore fuerunt, ut nihil quod ad poeticam spectaret desiderari posset: Nam in iis scribendis Aristotelis methodum seruauit: \& ex ipsius Libello de arte Poetica principia sumpsit omnium suarum explicationum, Basileae, Per Ioannem Hervagivm ivniorem, Anno M.D.L.V, (BJ St. Dr. Greka 3592).

${ }^{75}$ W. Urban, Akademia Krakowska, s. 291; H. Barycz, Glicius Marcin, [w:] PSB, t. 8, Wrocław-Kraków-Warszawa 1959-1960, s. 48-49; A. Lewicka-Kamińska, Biblioteka Jagiellońska, s. 182; Poczet rektorów, s. 152; L. Łętowski, Katalog biskupów, t. 2, s. 253-256. 
discputatio Eiusdem Laconici ... (BJ St. Dr. Neolatina 426 II). Dopiero później tom ten miał trafić do rąk Błażeja Bazylego Goliniusza ${ }^{76}$.

Zachariasz Starnigel (ok. 1582-1641), teolog i grecysta, profesor katedry grecystyki ufundowanej przez Andrzeja Schoneusa na Akademii Krakowskiej ${ }^{77}$, był właścicielem pracy Robortella o tragediach Ajschylosa Scholia in Aeschyli Tragaedias Omnes ex Vetvstissimis libris manuscriptis collecta..${ }^{78}$ oraz samych tragedii Tragodiai epta. Tragoediae septem ... ${ }^{79}$, których wydawcą był właśnie wspomniany padewski profesor. Z. Starnigel był również kustoszem biblioteki Collegium Maius w latach 1624-1632. On to zakończył wykładanie greki i zamienił jej katedrę na profesurę teologii ${ }^{80}$. Po śmierci wzmiankowany tom trafił zgodnie z wolą zmarłego do profesora greki (,„pro usu profesoris lingua gracae post mortam Zacharii Starnigieli’). (Il. 4).

Kolejny wybitny uczony padewskiej wszechnicy to Jacopo (Giacomo) Zabarella (1533-1589), filozof, logik, awerroista, znawca nauk humanistycznych, przyjaciel Polski i Polaków. W Padwie studiował u F. Robortella i Bernardina Tomitano, w 1564 r. objął katedrę logiki, w 1568 r. drugą katedrę filozofii naturalnej, aby w 1577 r. sięgnąć po pierwszą katedrę filozofii naturalnej, którą utrzymał do śmierci. Opublikował m.in.: Tabulae logicae, Patavii 1589; Opera quae in hunc diem edidit, libri 5, 1586; De doctrinae ordine Apologia, Patavii 1587; In duos Aristotelis libros Posteriores Analyticos commentarii, Venetiis 1587; De rebus naturalibus libri XXX, Colonie $1590^{81}$. Odrzucił propozycję Stefana Batorego, aby objać wykłady w krakowskiej uczelni, ale swe dzieło Opera logica, Venetiis, apud Paulun Meietum bibliopolam Patavinum, ed. 1578 r., dedykował polskiemu władcy. Również wspomniane dzieło pt. Opera, quae in hunc diem edidit, in quinque tomos divisa, Francofurdi typ. Joannis Wecheli 1586-1587 dedykował polskiemu królowi ${ }^{82}$. Słuchaczami Zabarelli byli m.in. Wojciech Szeliga z Warszawy (dr fil. i med. 21 czerwca 1582 r.), który opracował streszczenia wykładów Jacopa Zabarelli w 1579 r.: Lucidissima in Aristotelis De physico auditu libros Periphraseos... per me Albertum Scheliga fideliter

\footnotetext{
${ }^{76}$ A. Lewicka-Kamińska, Biblioteka Jagiellońska, s. 158.

${ }^{77}$ H. Gmiterek, Starnigel (Sterngel, Staryngelowicz, Starynglowicz) Zachariasz, [w:] PSB, t. 42, Warszawa-Kraków 2003-2004, s. 329; A. Lewicka-Kamińska, Biblioteka Jagiellońska, s. 271; Historia nauki polskiej, t. 6 , s. 643 .

${ }^{78}$ Scholia in Aeschyli Tragoedia omnes ex vetstissimis libris manuscriptis collecta, atq; in hoc corpus redacta..., Venetiis ex officina, Erasmiana Vincentij Valgrisii, MDLII (BJ St. Dr. Greka 28 (b)).

${ }^{79}$ AischylouTragodiai epta. Aeschyli Tragoediae septem. A Francisco Robortello..., Venetiis Apud Gualterium Scottum, MDL II (BJ St. Dr. Greka 28 (a)).

${ }^{80}$ W. Urban, Akademia Krakowska, s. 290; A. Lewicka-Kamińska, Biblioteka Jagiellońska, s. 219.

${ }^{81}$ www.plato.stanford.edu/entries/zabarella/, strona internetowa oglądana 18.05.2017; A. Poppi, Ricerche sulla teologia e la scienza nella scuola Padovana del Cinque e Seicento, Catanzaro 2001, s. 127-159; Scienza e filosofia all'università di Padova nel Quattrocento, a cura di A. Poppi, Trieste 1983, s. 135-202.

${ }^{82}$ S. Łempicki, Działalność Jana Zamoyskiego, s. 33, 49; S. Lachs, Krakowskie księgozbiory lekarskie, „Archiwum do dziejów literatury i oświaty w Polsce”, t. 13, 1914, s. 412; W. Wisłocki, Katalog rękopisów Biblioteki Uniwersytetu Jagiellońskiego, cz. II, Kraków 1877-1881, nr 2106; W. Rubczyński, Tracie di studi filosofici compiuti di Polacchii a Padova verso la fine del Cinquecento, [w:] Omaggio dell'Accademia Polacca di Scienze e Lettere all'Università di Padova nel settimo centenario della sua fondazione, Cracovia 1922, s. 345; K. Estreicher, Bibliografia polska, t. 34, Kraków 1951, s. 4, wnuk Jacopa Zabarelli, także Jacopo, opublikował dzieło pt.: Polonica sive originum Polonicarum Stemmata, Patavii apud Petrum Lucianum 1650, które dedykował królowi polskiemu Janowi Kazimierzowi. W dedykacji przypomniał o przywiązaniu swoich przodków do królów polskich, a mianowicie Jacopo Zabarella o przywiązaniu swego dziada, który nawet swoje dzieła o logice i filozofii poświęcił Zygmuntowi Augustowi i Stefanowi Batoremu.
} 
ex ore ipsius calamo excepta. Libri I Meteororum Excellentissimi comitis dni Jacobi Zabarellae, in celeberrrimo gymnasio Patavino, philosophiae extraordinarii in primo loco professori, diligentissima Explicatio a.d. 1579 (rękopis zachował się w zbiorach Biblioteki Jagiellońskiej), również Wawrzyniec Goślicki, autor dzieła De optimo senatore, libri duo, Venetiis 1568, a także Jan Zamoyski ${ }^{83}$. (Il. 5).

Z prac Iacopo Zabarelli wydanych w XVI w. w Bibliotece Jagiellońskiej znajduje się 9 tytułów w 18 egzemplarzach. Dwa jego dzieła występują w uniwersyteckiej bibliotece jako klocki introligatorskie. Dzieła logiczne Opera qvae in hvnc diem edidit..., wydane we Frankfurcie w latach 1586-1587 oraz księgi o naturze (raczej o przyrodzie) De rebvs natvralibvs libri $X X X$... (Kolonia 1590) ${ }^{84}$ to współoprawne tomy, które należały do dwóch krakowskich profesorów. Pierwszym był Bartłomiej Grzybowski z Lelowa, doktor filozofii, dziekan wydziału filozoficznego w 1618 i 1625 r., właściciel woluminu oznaczonego sygnaturą BJ St. Dr. Cim. 8739-8740. W 1639 r. był wykonawcą testamentu Daniela Sygoniusza $^{85}$. Część księgozbioru Bartłomieja Grzybowskiego trafiła po jego śmierci do Zygmunta Kosickiego lub Kozickiego, zw. Gregerowicem, rzymskiego doktora teologii w 1645 r., protonotariusza apostolskiego, prepozyta kolegiatury św. Floriana oraz rektora Akademii Krakowskiej ${ }^{86}$. Właścicielem drugiego takiego samego klocka składającego się z tych samych dzieł Zabarelli (BJ St. Dr. Cim. 8741-8742) był Marcin Gilewski (Gilevius, Gilovius, Bularny), żyjący w latach 1572-1630, doktor filozofii i teologii, uniwersytecki profesor i kanonik kolegiaty św. Floriana ${ }^{87}$.

Jan Racki (1610-1682) ${ }^{88}$, doktor filozofii i doktor teologii promocji rzymskiej, profesor i historiograf Akademii Krakowskiej, kanonik krakowski i królewski sekretarz, był posiadaczem czterech dzieł Zabarelli. Ten znawca klasycznych języków, retoryk i poeta odbył naukową podróż do Bolonii ${ }^{89}$ i być może wówczas zakupił prace Zabarelli. W jednym klocku introligatorskim (BJ St. Dr. Cim. 8848-8851) znajdują się dzieła z zakresu logiki ${ }^{90}$.

${ }^{83}$ L. Ćwikliński, Padwa i Polska, s. 94; Acta graduum academicorum Gymnasii Patavini ab anno 1566 ad annum 1600 (1576-1590), a cura di E. Martellozzo Forin, t. 4, parte 3, Roma-Padova 2008, nr 1626; W. Wisłocki, Katalog rękopisów Biblioteki Uniwersytetu Jagiellońskiego, cz. II, nr 2106; K. Estreicher, Bibliografia polska, t. 17, Kraków 1899, s. 276.

${ }^{84}$ Iacobi Zabarellae... Opera qvae in hvnc diem edidit, in quinq; tomos diuisa, Apud Ioann. Mareschallum Lugdunensem, [post 1 IX] MDLXXXVI - MDLXXXVII. (Francofvrdi Typis Ioannis Wecheli), (BJ St. Dr. Cim. 8740) współoprawne z: Iacobi Zabarellae... De rebvs natvralibvs libri XXX. Quibus quaestiones, quae ab Aristotelis interpretibus hodie tractari solent, accurate discutiuntur, Coloniae Ioannis Baptistae Ciotti Senensis aere. [post 17 III] cIcIccxc, (BJ St. Dr. Cim. 8739).

${ }^{85}$ A. Lewicka-Kamińska, Biblioteka Jagiellońska, s. 184.

${ }^{86}$ Ibidem, s. 171; A. Przyboś, Akademia Krakowska, s. 333; Poczet rektorów, s. 183. Swój księgozbiór Zygmunt Gregerowic ofiarował bibliotece Kolegium Większego.

${ }^{87}$ Katalog poloników XVI wieku Biblioteki Jagiellońskiej, s. 263; A. Lewicka-Kamińska, Biblioteka Jagiellońska, s. 166.

${ }^{88}$ L. Hajdukiewicz, Racki (Radzki) Jan, [w:] PSB, t. 29, Wrocław-Warszawa-Kraków-Gdańsk-Łódź 1986, s. 604; Historia nauki polskiej, t. 6, s. 550-551.

${ }^{89}$ A. Przyboś, Akademia Krakowska w drugiej połowie w. XVII, s. 318 i 326.

${ }^{90}$ Iacobi Zabarellae... Opera logica. In hac Secunda Editione multis Annotationibus aucta, \& erroribus expurgata, tum in figuram quandam commodiorem digesta..., Venetiis, Apud Paulum Meietum Bibliopol. Patauinum, M.D.LXXXVI, (BJ St. Dr. Cim. 8848) współoprawne z: Iacobi Zabarellae ... De doctrinae ordine apologia. Tertio aeditioaeditio", Patauij, Apud Paulum Meietum. M.D.LXXXVII, (BJ St. Dr. Cim. 8851), Iacobii Zabarellae... In dvos Aristotelis libros posteriores analyticos commentarii, tertio editio. Cum antiqua Aristotelis in Latinum conuersione ab eodem cum Graecis exemplaribus diligentissime collata, \& omnibus mendis expurgata, 
Po śmierci Rackiego jego księgozbiór trafił do biblioteki Collegium Maius ${ }^{91}$. Racki był także właścicielem bazylejskiego wydania O pochodzeniu i czynach Polaków ksiag XXX... Marcina Kromera ze wstępem F. Robortella ${ }^{92}$. (Il. 6).

Inne wydanie prac Zabarelli dotyczących logiki Opera logica: Quorum ...93, mianowicie wydanie kolońskie z 1597 r., znalazło się w kręgu Akademii Krakowskiej dzięki bliżej nieznanemu Marcinowi Dzikowiczowi. Jak wynika z wpisu proweniencyjnego, został on bakałarzem w Krakowie i zakupił tę księgę w 1669 r. za 4 floreny 15 groszy od pewnego człowieka $w$ dobrej wierze.

Drugi egzemplarz Opera logica ... z 1597 r. ${ }^{94}$ (BJ St. Dr. Filozofia 2558 II [a]) oraz kolońskie wydanie, także z 1597 r., 30 ksiąg o naturze De rebvs natvralibvs libri XXX. Quibus quaestiones ... ${ }^{95}$ to księgi zakupione do biblioteki Collegium Maius w ramach fundacji Benedykta z Koźmina. Inny egzemplarz 30 ksiąg o naturze z 1597 r. (BJ St. Dr. Filozofia 2565 II) trafił do biblioteki uniwersyteckiej 29 czerwca 1817 r.; jego poprzednim właścicielem był Jacek Łopacki (1690-1761), kanonik krakowski, lekarz i mecenas sztuki, właściciel liczącej ponad 1000 tomów biblioteki ${ }^{96}$.

Bazylejskie wydanie prac Zabarelli z zakresu logiki Opera logica: Quorum ... ${ }^{97}$ należało do Andrzeja Buchowskiego (1662-1709), zajmującego się retoryką i geometrią profesora Akademii Krakowskiej ${ }^{98}$. Nie wiemy, kiedy księga ta wpłynęła do biblioteki Collegium Maius.

Kolejnym ze znanych ówczesnych profesorów padewskich był Marco Mantova Benavides (1489-1582), z pochodzenia Hiszpan, nobilitowany we Włoszech., doktor prawa cywilnego w 1511 r. oraz prawa kanonicznego w 1524 r. Już w 1517 r. Senat wenecki powierzył mu wykłady pt. Istitutioni Imperiali. Rok później otrzymał katedrę prawa cywilnego, a w 1523 r. przejął drugą katedrę prawa kanonicznego. Odrzucił proponowaną mu katedrę na Uniwersytecie Bolońskim, natomiast od 1534 r. sprawował urząd rektora Collegio dei Giuristi. Po wielu latach nauczania przesunięty został na pierwszą katedrę prawa cywil-

\footnotetext{
Venetiis, Apud Paulum Meietum... M.D.LXXXVII, (BJ St. Dr. Cim. 8850) oraz Iacobi Zabarellae... Tabvlae logicae... quarto editae, Patauij, Apud Paulum Meietum. M.D.LXXXIX (BJ St. Dr. Cim. 8849).

${ }^{91}$ A. Lewicka-Kamińska, Biblioteka Jagiellońska, s. 226.

${ }^{92}$ Martini Cromeri De Origine Et Rebus Gestis Polonorum Libri XXX; Adiecta est in fine, eiusdem autoris funebris Oratio Sigismundi Regis vitam compendiose complexa, \& aliquoties iam prius edita. Acceßit iudicium Francisci Robortello... de autore \& libro, Basileae, Per Ioannem Oporinum, M.D.LVIII (BJ St. Dr. Cim. 8488).

${ }^{93}$ Iacobi Zabarellae... Opera logica: Quorum ... affixa Praefatio Ioannis Lvdovici Havvenrevteri... Editio tertia, Coloniae, Sumptibus Lazari Zetzneri. cIc.Ic.XCVII, (BJ St. Dr. 932710 II).

${ }^{94}$ Iacobi Zabarellae... Opera logica: Quorum ... affixa Praefatio Ioannis Lvdovici Havvenrevteri... Editio tertia, Coloniae, Sumptibus Lazari Zetzneri. cIc.Ic.XCVII (BJ St. Dr. Filoz. 2558 (a).

${ }^{95}$ Iacobi Zabarellae... De rebvs natvralibvs libri XXX. Quibus quaestiones, quae ab Aristotelis interpretibus hodie tractari solent, accurate discutiuntur. Editio tertia, Coloniae, Sumptibus Lazari Zatzneri. [post 1 II] cIcIcXCVII (BJ St. Dr. Filoz. 2558 (b).

${ }^{96}$ Z. Gajda, Jacek Augustyn Łopacki. Studium z dziejów kultury medycznej w Krakowie w XVIII w., Wrocław-Warszawa-Kraków 1969, s. 152-156; Z. Gajda i J. Lepiarczyk, Eopacki Jacek Augustyn, [w:] PSB, t. 18, Wrocław-Warszawa-Kraków-Gdańsk 1973, s. 405; Historia nauki polskiej, t. 6, s. 380.

${ }^{97}$ Iacobi Zabarellae... Opera logica: Quorum ... affixa Praefatio Ioannis Lvdovici Havvenrevteri... ([Acc.:] Iacobi Zabarellae... De doctrinae ordine apologia. Nvnc mvlto correctior quam antea edita. Iacobi Zabarellae... Tabvlae logicae ... qvinto editae.), Basiliae Typis Conradi Valdkirchii: Impensis Lazari Zetzneri, \& Petri Mareschalli. [post 14 VIII] cIcIcXCIV (BJ St. Dr. Filoz. 2562).

${ }^{98}$ H. Barycz, Buchowski Andrzej, [w:] PSB, t. 3, Kraków 1937, s. 78-79; Historia nauki polskiej, t. 6, s. $67-68$.
} 
nego, zaś w latach 1572-1573 otrzymał pierwszą katedrę prawa kościelnego. Jako konsultant prawny cesarza Karola V Habsburga (1545) oraz arcyksięcia Ferdynanda Habsburga został mianowany przez niego w $1561 \mathrm{r}$. kawalerem i hrabią palatynu, z kolei papież Paweł III powołał go w charakterze sędziego do Trybunału Sacra Rota przy Stolicy Apostolskiej. Benavides uchodził za wytrawnego prawnika, humanistę, literata oraz kolekcjonera. Dziś jego zbiór znajduje się w Museo di Scienze Archeologiche e d'Arte w Padwie (od 2008 r.) w kolekcji starożytnych arcydzieł oraz dzieł. Jego biblioteka liczyła przeszło 1700 woluminów. Był badaczem bardzo płodnym i pozostawił interesującą spuściznę naukową, jak choćby następujące dzieła: Speculi vitae opus, Patavii 1579; Ephemerologium, Patavii 1579; Epitoma virorum illustrium, Patavii 1555; Dialogus de concillio, Venetiis 1541; Responsa ac defensiones, Venetiis 1543; czy Illustrium iureconsultorum imagines, Romae 1566, w którym opisał najsławniejszych prawników i literatów swego czasu ${ }^{99}$.

W zbiorach Biblioteki Jagiellońskiej znajdujemy 3 tytuły dzieł Marca Mantovy Benavidesa, mianowicie: Ephemerologivm nvnc primvm in stvdiosorum ... ${ }^{100}$, Psalmorvm exqvsita paraphrasis qva stvdiosi sacrvm ... ${ }^{101}$ oraz Specvli vitae opvs .. ${ }^{102}$ Składają się one na klocek introligatorski, którego właścicielem był biskup Piotr Wolski.

Równocześnie z Marco Mantova Benavidesem wykładał na Uniwersytecie Padewskim prawnik, historiograf, filolog klasyczny i humanista Antonio Riccoboni (1541-1599). W 1569 r. przejął najpierw katedrę elokwencji (retoryki), a następnie po Bernardinie Tomitano - logiki, którą utrzymał przez 30 lat. Zmarł w wieku 58 lat. Riccoboni był autorem m.in. De historia commentarius, Venetiis 1568; autorem komentarzy do Etyki i Poetyki Arystotelesa oraz Commentarii de gymnasio Patavino, 1598, dalej Orationum, Patavii 1592 i Humanitatis in Patavino Gymnasio explicatoris poetica Aristotelis, ed. Vincetiae $1585^{103}$. Studenci polscy bardzo Riccoboniego cenili; pod jego kierunkiem w 1575 r. prawo i retorykę studiował Jan Januszewski, syn Łazarza Andrysowicza $1575^{104}$, zaś jego wykładów słuchali m.in.: Andrzej Patrycy Nidecki, Jan Zeleński (1579 r., o którym pisze sam A. Riccoboni w swym dziele pt. De gymnasio Patavino ed. w 1598), Zbigniew Ossoliński (1575-1576) ${ }^{105}$, Wojciech Baranowski, Jan Sapieha (1587), Adam Czajkowski (1586), Piotr Czerny (1586), Marcin Ciesielski (1591), Hieronim Powodowski (1571-1574), jezuita Wojciech Rościszewski (1583) ${ }^{106}$.

${ }^{99}$ F. Tomasi, C. Zendri, Mantova Benevides Marco, [w:] Dizionario Biografio degli Italiani, t. 69, Roma 2007, s. 214-219.

${ }^{100}$ M. Mantvae ae Benevidi Patavini, Ephemerologivm primvm in stvdiosorvm gratiam editum, Patauii, Laurentius Pasq. excudebat. MDLXXIX (BJ St. Dr. 593535 I).

${ }^{101}$ Psalmorvm salmorvm exqvisita paraphrases qua stvdiosi sacrarvm Literarum diligenter in fide exercean$t u r$, in Padova, per Lorenzo Pasquati. MDLXXVII (BJ St. Dr. 593537 I).

${ }^{102}$ Specvli vitae opvs... nunc primum in studiosorum gratiam editum, Patauii, Laurentius Pasq. Excudebat. MDLXXIX (BJ St. Dr. 593336 I).

${ }^{103}$ H. Barycz, Z epoki renesansu, s. 196.

${ }^{104}$ M. Lenart, Studenti Polacchi a Padova e loro mecenatismo in Patria, s. 510; J. Kiliańczyk-Zięba, Czcionkq i piórem -Jan Januszowski w roli pisarza i tlumacza, Kraków 2007, s. 49; St. Windakiewicz, Padwa, s. 62.

${ }^{105}$ Historia literatury, t. 6, s. 74-75; St. Windakiewicz, Padwa, s. 62; Acta graduum academicorum, t. 4, parte 2, nr 1016, 1017 (Osolinski Sbigneus, 1575). W Padwie Z. Ossoliński przebywał od maja 1575 do początków 1576 r. Zob. W. Czapliński, Ossoliński Zbigniew, [w:] PSB, t. 24, Wrocław-Warszawa-Kraków-Gdańsk 1979, 428; K. Estreicher, Bibliografia polska, t. 26, Kraków 1915, s. 298; Antonio Riccoboni w dziele pt. Commentarii de Gymanasio Patavino, Patavii 1598 na s. 95 wspomina: Jacobus Zelenius Polonus Antonio Riccobono S.D.

106 St. Windakiewicz, Padwa, s. 62-64, 66, 90; Wojciecha z Kalisza Szkoła Lenartowska, ed. S. Kot, „Archiwum do dziejów kultury i oświaty w Polsce”, t. 13, 1914, s. 327 Piotr Czerny był siostrzeńcem Jana Zamoy- 
Z prac Antonia Riccoboniego w krakowskiej bibliotece uniwersyteckiej znajdują się 4 dzieła w 6 egzemplarzach. Tom zawierający komentarze o sztuce Arystotelesa, De vsv artis rhetoricae Aristotelis commentarii vigintiqvinqve... ${ }^{107}$, zanim trafił do biblioteki Collegium Maius, należał do dwóch wybitnych ludzi nauki. Pierwszym był Erazm Sykst (1570-1635), student Akademii Krakowskiej od 1591 r., bakałarz w 1593, magister atrium i doktor filozofii, padewski doktor medycyny, profesor Akademii Zamojskiej i lwowski lekarz (od 1627 r.) ${ }^{108}$. Drugim był Łukasz Piotrowski (zm. 1679), doktor filozofii, profesor krakowskiej uczelni ${ }^{109}$, który zebrał jedną z najciekawszych bibliotek filologicznych XVII w. Z pozostawionych zapisków Ł. Piotrowski jawi się jako pilny, uważny czytelnik ${ }^{110}$. Jego cenny księgozbiór trafił do biblioteki Collegium Maius ${ }^{111}$. W omawianej księdze znajdują się jeszcze dwa wpisy proweniencyjne nieznanych bliżej osób: Albertusa (Wojciecha) Mitaya oraz Macieja Gruatiusa (Gruatio). W księgozbiorze Ł. Piotrowskiego można znaleźć także Aristotelis... Ethicorvm Liber Primus... dzieło, które opatrzone jest uwagami oraz interpretacjami Riccoboniego ${ }^{112}$.

Wspomniany wcześniej rektor Akademii Krakowskiej, Andrzej Kucharski, to właściciel dwóch tomów modlitw Riccoboniego. Były to jednak dwa różne wydania: Orationvm Volvmen Primum ... (Padwa 1592) $)^{113}$ oraz Orationvm Volumen Secundum ... (Padwa 1591) ${ }^{114}$. Drugi egzemplarz pierwszego tomu ${ }^{115}$ należał do Stanisława Jurkowskiego (1601-1669), doktora teologii promocji rzymskiej. Zwiedził on Rzym i Pizę, studiował w Paryżu i Lowanium. Był profesorem wymowy w Akademii Lubrańskiego w Poznaniu, profesorem Szkół Nowodworskich, wreszcie profesorem Akademii Krakowskiej, kilkukrotnym rektorem, prowizorem biblioteki Collegium Maius, cenionym za życia za pracę organizacyjną na uniwersytecie ${ }^{116}$. Do S. Jurkowskiego należało także dzieło Arystotelesa z komentarzami Riccoboniego i C. Sigonia Aristotelous Technes retorikes biblia ... ${ }^{117}$.

skiego i uczniem Riccoboniego; Marcin Ciesielski drukował w Padwie 1591 r. Ad Petrum Marcellum praefecti patavini oratio oraz Oratio gratulatoria ad Illustriss, et Rewerend. D.D. Georgium Radivilum S.R.E.cardinalem, Crac. episcopol, Patavii apud Laurentium Pasquatum 1591: K. Estreicher, Bibliografia polska, t. 14, Kraków 1896, s. 284.

${ }^{107}$ Antonii Riccoboni De vsv artis rhetoricae Aristotelis commentarii vigintiqvinqve,... Qvibvs accessit eivsdem ... a Io. Mario Matio... dissensio de quibusdam locis Quintiliani probantibus Rhetorica ad Herennium esse Cornificij, M.D.XCV.... Francoforti, Apud Andreae Wecheli heredes, Claudium Marnium, \& Ioan. Aubrium (BJ St. Dr. Gram. 3764 (a).

${ }^{108}$ Acta graduum academicorum Gimnasii Patavini ab anno 1566 ad annum 1600, a cura di E. Martellozzo Forin, t. 4, parte 3, Roma-Padova 2008, nr 32, 319, 321, 322, 324, 515; Historia nauki polskiej, t. 6, oprac. L. Hajdukiewicz, s. 665-666; F. Giedroyć, Źródta biograficzno-bibliograficzne do dziejów medycyny w dawnej Polsce, Warszawa 1911, s. 779-781; S. Gąsiorowski i M. Kapral, Sykst (Sikstus, Syxt, właśc. Mrzyglód), [w:] PSB, t. 46, Warszawa-Kraków 2009-2010, s. 207-210.

${ }^{109}$ M. Michalewiczowa, Piotrowski, s. 489.

${ }^{110}$ A. Lewicka-Kamińska, Biblioteka Jagiellońska, s. 353.

${ }^{111}$ Ibidem, s. 226.

${ }^{112}$ Aristotelis... Ethicorvm Liber primvs (-tertius) Antonio Riccobono Interprete, Secundo Editus, Patavii, Apud Laurentium Pasquatum..., M.D.XCIII (BJ St. Dr. Greka 253).

${ }^{113}$ Antonii Riccoboni Orationum Volvmen Primum, secundo editum, Ad... Lavrentivm Massam..., Patavii, Apud Paullum Meietum, 1592 (BJ St. Dr. Teol. 5707 (b)).

${ }^{114}$ Antonii Riccobomi Orationum Volumen Secundum ad... D. Antonium Salvlivm, Patauii, Apud Laurentium Pasq. M.D.LXXXXI, (BJ St. Dr. Teol. 5707 (c)).

${ }^{115}$ BJ St. Dr. 932711 II.

${ }^{116}$ A. Przyboś, Akademia Krakowska w drugiej połowie w. XVII, s. 324.

${ }^{117}$ Aristotelous Technes retorikes biblia 3. Aristotelis Artis rhetoricae libri tres; ab Antonio Riccoboni Latine conuersi. Eivsdem Rhetoricae Paraphrasis, interiecta rerum explicatione, \& collata Riccoboni multis in locis con- 
Rzecz o poetyce Poetica Antonii Riccoboni... Poeticam Aristotelis per paraphrasim explicans ... ${ }^{118}$ należała do wspomnianego wyżej Jana Rackiego (1610-1682). Oczywiście w księgozbiorze biskupa Wolskiego nie mogło zabraknąć prac Antonia Riccoboniego: w dziele zbiorowym Artis historicae penus octodecim scriptorum..., wydrukowano jego rozprawę De historia... ${ }^{119}$.

Podsumowując powyższe rozważania, warto zastanowić się, jakimi drogami omówione dzieła padewskich uczonych trafiły do zbiorów biblioteki Collegium Maius. Z przeprowadzonej dotąd kwerendy w Archivio Antico dell'Università di Padova, jak i dostępnej literatury przedmiotu wynika, że wśród cudzoziemców - po nacji germańskiej - Polacy stanowili najliczniejszą grupę. Ich liczba znacznie zwiększyła się po 1530 r., można przyjąć, że rok rocznie studiowało w Padwie co najmniej kilkudziesięciu Polaków. G. Maver w swej opublikowanej w 1923 r. pracy I Polacchi all'Università di Padova podaje, że w latach 1560-1570 na Uniwersytecie Padewskim studiowało od 40-60 studentów prawa $^{120}$. Przykładowo z opublikowanej przez Blasio Brugi i Aloysio Andrich w $1892 \mathrm{r}$. metryki Natio Polona, obejmującej tak prawników, jak i artystów (ale zapewne tylko część studiujących w Padwie Polaków), dowiadujemy się, że tylko w 1592 r. wpisało się 56 Polaków $^{121}$. Do odnalezionej Matriculazione Università Legista Polona z lat 1591-1598 wpisało się 83 studentów polskich, wśród których 20 było dotąd nieznanych. Ponadto w $\mathrm{Ma}$ tricula Legista Natione Germana znajdujemy 11 scholarów pochodzących z Gdańska oraz Torunia ${ }^{122}$.

I. Przyjąć trzeba, że wszyscy Polacy studiujący prawo, filozofię oraz teologię musieli być słuchaczami wymienionych wyżej profesorów i mogli nabywać najnowsze publikacje swoich mistrzów. O tym, że Polacy kupowali w Padwie rozmaite dzieła, świadczy pojedynczy przykład. W 1580 r. do Polski nadeszła wiadomość o zgonie franciszkańskiego brata Stanisława Bonawentury z Krakowa, który swój księgozbiór, liczący 1000 tomów, zapisał polskim studentom w Padwie ${ }^{123}$. Znaczna liczba znakomitych dzieł padewskich profesorów dostała się bibliotece Collegium Maius przez darowiznę dzieł zagranicznych autorów, dokonaną przez biskupa płockiego Piotra Dunin-Wolskiego (m.in. Marca Mantovy Benevidesa, Francesca Robortella, Carla Sigonia). W Padwie studiował w latach

versione cum Maioragij, Sigonii, Victorii et Mureti conversionibus, separatim est edita, Francofvrdi Apud haeredes Andreae Wecheli, Claudium Marnium et Ioannem Aubrium, MDLXXXVIII (BJ St. Dr. Greka 234).

${ }^{118}$ Poetica Antonii Riccoboni C. Hvmanitatis in Patavino Gymnasio Expliicatoris, Poeticam Aristotelis per paraphrasim explicans, \& nonnullas Ludouici Casteluetrij captiones reffellens. Eivsdem ex Aristotele Ars Comica, VICETIAE [!], Apud Perinum Bibliopolam, \& Georgium Gręcum Socios, CIC.IC.LXXXV (BJ St. Dr. Cim. 6390).

${ }^{119}$ Artis historiae penvs Octodecim Scriptorum tam veterum quam recentiorum monumentis \& [...] (Antonio Riccobonus de Historia \& de ea veterum fragmenta recens adiuncta), Basileae, Ex officina Petri Pernae, CICICLXXXIX (BJ St. Dr. 590169 I).

${ }^{120}$ Obliczenia własne autora oraz podane na podstawie literatury przedmiotu m.in. G. Fedalto, Studenti stranieri a Venezia e a Padova 1550-1700, [w:] Storia della cultura veneta, Il Seicento, vol. 4, parte 2, Vicenza 1984, s. 277. Autor ten podaje cyt.: „Nel Cinquecento furono circa 1.400 gli studenti polacchi”; G. Maver, I Polacchi all'Università di Padova, s. 58.

${ }^{121}$ Natio Polona. Rotulus et matricola D.D. Juristarum et Artistarum Gymnasii Patavini A MDXCII-II, s. $10-11$.

${ }^{122}$ Archivio Antico dell’Università di Padova, rkps 30 (dawna sygnatura 677 zbioru Minato), s. 10v-30v oraz $43 \mathrm{r}-46 \mathrm{v}$.

${ }^{123}$ K. Kantak, Franciszkanie polscy, t. 2 1517-1795, Kraków 1938, s. 232. 
1549-1550, cieszył się opinią świetnego dyplomaty, mającego liczne znajomości we Włoszech i doskonale władającego językiem włoskim ${ }^{124}$.

II. Z okresu od 1511 do 1592 r. posiadamy 28 protokołów przewodów doktorskich Polaków z zakresu prawa, filozofii i teologii. Podkreślić jednak trzeba, że wiele protokołów z egzaminów doktorskich nie zachowało się do dzisiaj ${ }^{125}$. Ich promotorami oraz członkami komisji doktorskich byli omawiani profesorowie. Jest prawie pewne, że polscy doktorzy nabywali ich dzieła, które przywozili ze sobą do ojczyzny. Przytoczmy ich nazwiska w układzie chronologicznym:

1. Erazm Morsztyn, dr praw 3 października 1511 r. (promotor Bartolomeo z Urbino) ${ }^{126}$.

2. Stanisław Przeborowski, dr praw 8 maja 1529 r. ${ }^{127}$

3. Hieronim Łopatecki, dr praw 21 października 1533 r. (promotor Marco Mantova Benevides) $)^{128}$.

4. Jan Ostrowicki, dr praw 14 czerwca 1535 r. $^{129}$

5. Jan Wilanowski, dr praw 20 września 1535 r. ${ }^{130}$

6. Jerzy Albinus (Biały), dr praw 3 kwietnia 1540 r. (promotorzy: Guido Panciroli i Bartolomeo Salvatico ${ }^{131}$.

7. Klemens Janicki, dr filozofii 22 lipca 1540 r. ${ }^{132}$

8. Szymon Maricjusz Kociołek, dr praw Ferrara 1545 r. (uczeń Lazzara Bonamica 1548 r.) $)^{133}$.

9. Paweł z Mąkolna, dr praw 26 marca 1549 r. ${ }^{134}$

10. Jan Lanckoroński, dr filozofii 9 lipca 1551 r.?

11. Stanisław Szędziński, dr praw 25 lutego 1557 r. (promotorzy: Guido Panciroli, Marco Mantova Benevides oraz Jacopo Zabarella) $)^{135}$.

\footnotetext{
${ }^{124}$ Acta graduum academicorum Gymnasii Patavini ab anno 1538 ad annum 1550, t. 3, parte 3, nr 3921 .

${ }^{125}$ Choć Acta Universitatis Legistarum należą do najobszerniejszych i dobrze zachowanych, nie są jednak kompletne. Brak jest dokumentów z egzaminów i nadawania stopni doktorskich z następujących lat: 1564-1566, 1594-1600. Większe luki, jeśli chodzi o zachowane dokumenty z przewodów doktorskich, notujemy w Acta Universitatis Artistarum et Medicorum, a to: $\mathrm{z}$ lat 1500-1508, 1523-1524, 1526-1530, 1549-1554, 1566, 1584 i 1597.

${ }^{126}$ Acta graduum academicorum Gymnasii Patavini ab anno 1501 ad annum 1525, t. 3, parte 1, a cura di E. Martellozzo Forin, Padova 1969, nr 631.

${ }^{127}$ Ibidem, nr 1494.

${ }^{128}$ Acta graduum academicorum Gymnasii Patavini ab anno 1526 ad annum 1537, t. III, parte 2, a cura di E. Martellozzo Forin, Padova 1970, nr 1983. Może doktorem praw był także Marcin Dąbrowski zw. Kłap, który w latach 1533-1535 w Padwie studiował prawo i 28 marca 1538 r. jako dr praw instalował się na archidiakonię pszczewską. Zob.: H. Barycz, Polacy na studiach w Rzymie, s. 97, przypis 1; Acta graduum academicorum, t. III, parte 2, nr 3915.

${ }^{129}$ Ibidem, nr 3915.

${ }^{130}$ Ibidem, nr 2166.

${ }^{131}$ Acta graduum academicorum Gymnasii Patavini ab anno 1538 ad annum 1550, t. 3, parte 3, nr 2700.

${ }^{132}$ L. Ćwikliński, O wawrzynie doktorskim i poetyckim Klemensa Janickiego, „Rozprawy Wydziału Filologicznego Polskiej Akademii Nauk w Krakowie”, t. 58, nr 6, 1919, s. 1-37, dyplom promocji s. 32-37, promotorem rozprawy doktorskiej Klemensa Janickiego był znany profesor medycyny Giovanni Baptysta Montano; M. Cytowska, Janicki Klemens, [w:] PSB, t. 10, Wrocław-Warszawa-Kraków 1962, s. 504.

${ }^{133}$ H. Barycz, Maricjusz Szymon, [w:] PSB, t. 20, Wrocław-Warszawa-Kraków-Gdańsk 1975, s. 13; Acta graduum, t. 3, parte 3, nr 3539 .

${ }^{134}$ Ibidem, nr 3669.

${ }^{135}$ Acta graduum academicorum Gymnasii Patavini ab anno 1551 ad annum 1565, t. 4, parte 1, nr 626.
} 
12. Andrzej Patrycy Nidecki, dr praw 22 marca 1559 r. (promotorzy: Francesco Robortello, Antonio Riccoboni, Carlo Sigonio i Lazzaro Bonamico ${ }^{136}$.

13. Piotr Guteter, dr praw 30 lipca 1562 r. (promotor Guido Panciroli) ${ }^{137}$.

14. Jakub Udrzycki, dr praw 5 maja 1565 r. (promotorzy: Guido Panciroli i Geronimo a Vallibus $)^{138}$.

15. Stanisław (Clovius) Główczyc, dr praw 6 kwietnia 1566 r. ${ }^{139}$

16. Łukasz Gise (Gyss), dr praw 23 grudnia 1567 r. (promotor: Guido Panciroli) ${ }^{140}$.

17. Tomasz Gynter, dr teologii 18 stycznia 1570 r. ${ }^{141}$

18. Jakub Brzeźnicki, dr praw 1 lipca 1574 r. (promotorzy: Bernardino Tomitano oraz Arcangelo Mercenari, obecny był także Melchiorre Guilandini) ${ }^{142}$.

19. Marcin Łaszcz, dr praw 31 maja 1575 r. $^{143}$

20. Marcin z Ujazdu, dr teologii 1579 r. ${ }^{144}$

21. Melchior Petrykowski (Petricius), dr praw 1580 r. ${ }^{145}$

22. Sebastian Sylwiusz, dr praw 10 września 1584 r. (promotorzy: Guido Panciroli, Annibale Saviolo) ${ }^{146}$.

23. Grzegorz Dobrocki, dr praw 22 grudnia 1587 r. ${ }^{147}$

24. Franciszek Xaiercius, dr praw 22 grudnia 1587 r. ${ }^{148}$

25. Jan Gislerus z Gdańska, dr praw 1592 r. (promotor Guido Panciroli) ${ }^{149}$.

26. Jerzy Scipiades Sowiński, dr praw 13 lutego 1593 r. (promotorzy: Guido Panciroli i Luca Salvioli) $)^{150}$.

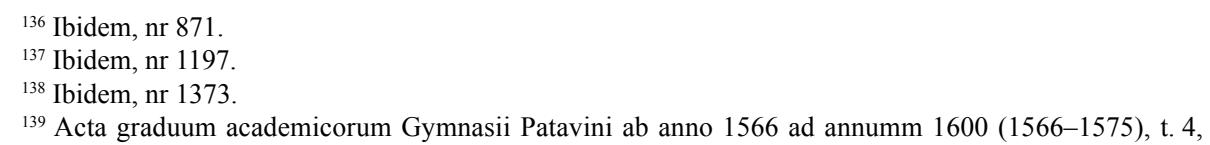
parte $2, \mathrm{nr} 38$.

${ }^{140}$ Ibidem, nr 208.

${ }^{141}$ Ibidem, nr 479.

${ }_{142}$ Ibidem, nr 934; M. R. Davi, Bernardino Tomitano filosofo, medico e letterato, Trieste 1995, s. 39, 54-57. Również Bernardino Tomitano darzył sympatią Polaków Polskę. Pozostawił łacińskie wiersze dedykowane polskiemu królowi Henrykowi Walezemu z okazji jego przejazdu przez Padwę i Wenecję w 1574 r. w drodze do Francji. Jedna z wielu jego głównych prac Animadversiones.aliquot in Primum librum Posteriorum Resolutioriorum ... in Aristotelis et Averrois dicta, Venetiis apud haeredes Lucae Antonii Junta (zawierająca komentarz do drugich Analityk Arystotelesa) była przygotowana oraz wydana z wielkim trudem i staraniem przez jego ucznia Jakuba (Breznieciusa) Brzeźnickiego, późniejszego biskupa sufragana poznańskiego. On też był autorem wstępu dedykowanego podeście Padwy Marino Cavalliemu oraz kapitanowi Padwy Niccolo Grittiemu. Ten ukłon w stosunku do reprezentantów Republiki w Padwie miał zachęcić władze weneckie do przekazania Tomitano katedry filozofii naturalnej; K. Estreicher, Bibliografia polska, t. 31, Kraków 1936, s. 220 .

143 Ibidem, nr 1019.

${ }^{144}$ Acta graduum academicorum Gymnasii Patavini ab anno 1566 ad annum 1600 (1576-1590), t. 4, parte 3, nr 1123; H. Barycz, Marcin z Ujazdu, [w:] PSB, t. 19, Wrocław-Warszawa-Kraków-Gdańsk 1974, s. 575.

${ }^{145}$ Acta graduum academicorum, t. IV, parte 3, nr 1420.

146 Ibidem, nr 1828.

${ }^{147}$ Ibidem, nr 2116.

${ }^{148}$ Ibidem, nr 2116.

${ }^{149}$ Acta graduum academicorum Gymnasii Patavini ab anno 1566 ad annum 1600 (1591-1600), t. 4, parte 4, nr 2733 .

${ }^{150}$ Ibidem, nr 2768. 
27. Mateusz Główczyc (Klowius), dr praw 23 września 1593 r. (promotorzy: Guido Panciroli, Bartolomeo Salvatico i Vittore Saxonia $)^{151}$.

28. Marcin Szyszkowski, dr praw 12 sierpnia 1594 r. (promotorzy: Marco Mantova Benedides oraz Tiberio Deciani) ${ }^{152}$.

29. Jan Gilewski, dr praw 31 maja 1602 r. (promotor Bartolomeo Salvatico) ${ }^{153}$.

30. Jerzy Muscovinius, dr praw 11 września 1603 r.

Z przytoczonych danych wynika, że w dziewięciu wypadkach promotorem prac doktorskich był Guido Panciroli, w trzech - Marco Mantova Benevides, poza tym w dwóch Bartolomeo Salvatico oraz jednorazowo promotorami byli: Jacopo Zabarella, Francesco Robortello, Carlo Sigonio, Lazzaro Bonamico, Bernardino Tomitano, Arcangelo Mercenari, Tiberio Deciani i Luca Salvioli. Jednak w protokołach przewodu doktorskiego nie zawsze wymienieni zostali promotorzy.

III. Niestety ani jeden z promowanych doktorów nie został zatrudniony w Akademii Krakowskiej, tak więc, jak można przypuszczać, ich zbiory trafiły bądź do ich miejsc pracy, zostały przekazane bibliotekom kościelnym, sprzedane lub zasiliły prywatne zbiory ich potomków. Padewscy prawnicy rozjechali się po całym kraju, obejmując wysokie stanowiska w hierarchii kościelnej i na dworze królewskim. Aby dowiedzieć się o ich księgozbiorach, potrzebna byłaby szczegółowa kwerenda źródłowa dotycząca przynajmniej wszystkich 28 doktorów. Można domniemywać, że promowany w 1574 r. na dr. obojga praw m.in. przez Arcangelo Mercenariego Jakub Brzeźnicki mógł przywieźć dzieła swego promotora. Posiadał bogaty księgozbiór. Nie jest wykluczone, że Marcin Glicjusz z Pilzna (1528-1591), szesnastokrotny rektor Akademii Krakowskiej oraz prokurator dóbr uniwersytetu, mógł zakupić dla Collegium Maius dzieło Francesca Robortelli: De arte poetica explicatione... in librum Aristotelis (ed. 1555) ${ }^{154}$.

IV. Wiemy też, że prace padewskich prawników, filozofów i filologów nabywali również polscy medycy, o czym świadczy zanotowany przypadek księgozbioru Stanisława Rożanki. Po obronie stopnia doktora filozofii i medycyny 12 maja 1556 r. powrócił on do rodzinnego Krakowa. W pozostawionym po jego śmierci w 1583 r. inwentarzu księgozbioru znajdujemy dzieło Francesca Robortelli poświęcone De arte poetica Arystotelesa ${ }^{155}$. Zdaniem Henryka Barycza był on głównym mistrzem Rożanki, który poznał język włoski, interesował się kulturą i przeszłością Italii i w swych zbiorach miał również Historię Italii Francesca Guicciardiniego oraz Historię Florencji Niccola Machiavellego ${ }^{156}$. Być może również Erazm Sekst ze Lwowa, który uzyskał dr filozofii i medycyny w Padwie 3 marca 1602 r., przywiózł do Polski m.in. dzieła profesora Antonia Riccoboniego (De usu artis rhetoricae Aristotelis, ed. 1595). Dzieła wspomnianych padewskich profesorów posiadał

\footnotetext{
${ }^{151}$ Ibidem, nr 2852.

152 Ibidem, nr 2948.

${ }^{153}$ Acta graduum Gymnasii Patavini ab anno 1601 ad annum 1605, a cura di F. Zen Benetti, Padova 1987,

${ }^{154}$ W. Urban, Akademia Krakowska $w$ dobie reformacji, s. 263, 263, 265, 277, 291, 300.

${ }^{155}$ Archiwum Narodowe w Krakowie (dalej cyt. AN-Kr), Advocatalia cracoviensia, rkps 181, s. 871-889; J. Lachs, s. 350; H. Barycz, Z epoki renesansu, s. 412.

${ }^{156}$ J. Lachs, Krakowskie księgozbiory lekarskie, s. 350, 365.
} nr 442 . 
w swym księgozbiorze włoski medyk króla Stefana Batorego, Simone Simoni. W zachowanym Inventarrius librorum d. doctoris Simonis Simony z 1585 r. znajdujemy m.in. Francesca Robortelli Aliorum lectiones oraz tegoż Aliorum quinque lectiones, Giovanniego Baptistae Montany: In Avicenna oraz In S. et Fenaricennae, Dialogus Carla Sigonia oraz Antonia Riccoboniego De carte rethorica et poetica ${ }^{157}$.

V. Dzieła padewskich uczonych z XVI w. nabywali też polscy scholarze studiujący w Padwie w następnym stuleciu. Zdarzały się przypadki przekazania do biblioteki Collegium Maius dzieł uczonych padewskich z XVI w. w następnym stuleciu. Treści wielu ich prac nie dewaluowały się i pozostawały nadal aktualne także w kolejnych wiekach. Jako przykład może posłużyć opisana już wyżej darowizna. Doktor, dziekan kościoła św. Floriana w Krakowie, proboszcz w Korczynie, profesor Akademii Krakowskiej - Marcin Gilewski (zm. 1630 r.), zostawszy jednym z egzekutorów testamentu zmarłego w 1625 r. kanonika krakowskiego, profesora oraz rektora Akademii Krakowskiej - Błażeja Bazylego Goliniusza, wypełniając wolę zmarłego, przekazał bibliotece Collegium Maius dzieło Francesca Robortelli pt. De historia facultate ${ }^{158}$. Podobnie mogło być z pracami Antonia Riccoboniego - pierwszym i drugim tomem Orationum (ed. w Wenecji 1591 i 1592 r.), które raz Andrzej Kucharski kanonik krakowski i dr teologii (1610) mógł odstąpić Stanisławowi Jurkowskiemu (1601-1669), studiującemu w Padwie (1638), dr. teologii z rzymskiej Sapienzy w 1642 r. (nostryfikacja tego stopnia odbyła się w 1649 r. $)^{159}$. Jesteśmy prawie pewni, że dzieło Francesca Robortelli Scholia in Aeschyli tragoedias (ed. 1552) przekazał bibliotece Collegium Maius profesor Zachariasz Starnigel z Buska (1582-1647), który zakończył nauczanie greki w Akademii Krakowskiej, zamieniając jej katedrę na profesurę teologii, ale wykłady języka greckiego kontynuował Adam Draski ${ }^{160}$. Prace Jacopa Zabarelli mógł zakupić we Włoszech Jan Racki (16101682), dr filozofii oraz dr teologii z rzymskiej Sapienzy (1679), retoryk, rymopis i znawca języków klasycznych ${ }^{161}$. Najwięcej nabytków otrzymała biblioteka Collegium Maius za czasów profesora Jan Brożka (1585-1652) z Krzelowa, który w latach 1631-1638 pełnił funkcję bibliotekarza. Ten wybitny polski matematyk, znawca geometrii praktycznej, logarytmów oraz ułamków był w latach 1620-1624 studentem Uniwersytetu Padewskiego. I zapewne to on przywiózł, a także kupował, dzieła padewskich uczonych dla krakowskiej biblioteki ${ }^{162}$.

VI. Dzieła znanych profesorów prawa, filozofii i filologii mogli też nabywać polscy studenci studiujący w Bolonii, gdzie m.in. w latach 1563-1584 wykładał Carlo Sigonio.

\footnotetext{
${ }^{157}$ AN-Kr, Advocatialia cracoviensia, t. 205, f. 898, 906-910, 914. Ponadto posiadał też dzieła padewskich profesorów medycyny: Gabriela Falloppia, Girolamo Mercuriale, oraz znanego lekarza włoskiego Pietra Andrei Matthioliego.

${ }^{158}$ L. Hajdukiewicz, Goliniusz Błażej Bazyli, s. 221-223. Marcin Gilewski był autorem ciekawych notatek dotyczących życia krakowskich profesorów, zmarł w $1630 \mathrm{r}$.

${ }^{159}$ A. Przyboś, Akademia Krakowska w drugiej połowie XVII w., s. 324, 326, 333-335; Archiwum nacji polskiej, s. 286.

${ }^{160}$ W. Urban, Akademia Krakowska, s. 268-269, 290.

${ }^{161}$ A. Przyboś, Akademia Krakowska, s. 318.

${ }^{162}$ W. Urban, Akademia Krakowska, s. 307; Archiwum nacji polskiej, s. 234.
} 
VII. Jakaś część dzieł wspomnianych padewskich profesorów była zapewne przekazywana na drodze zapisu testamentowego przez byłych doktorów i studentów padewskich na rzecz biblioteki Collegium Maius.

VIII. Można też założyć, że interesujące dzieła padewskich uczonych, kuratorzy Collegium Maius prawdopodobnie zakupywali u krakowskich księgarzy, a także na zagranicznych targach.

IX. Dzieła padewskich profesorów zasilały też księgozbiory krakowskich zakonów, które na drodze zakupu, legatu lub zrzeczenia trafiły do biblioteki Collegium Maius Akademii Krakowskiej.

\section{Bibliografia}

Żródła archiwalne:

Archivio Antico dell'Università di Padova, rkps 30.

Archivio Antico dell'Università di Padova, Natio Polona. Rotulus et matricola D.D. Juristarum et Artistarum Gymnasii Patavini A. MDXCII.

Archiwum Narodowe w Krakowie, Advocatialia cracoviensia, rkps 181, 205.

Źródła drukowane:

Acta graduum academicorum Gymnasii Patavini ab anno 1501 ad annum 1525, t. III, parte 1, a cura di E. Martellozzo Forin, Padova 1969.

Acta graduum academicorum Gymnasii Patavini ab anno 1526 ad annum 1537, t. III, parte 2, a cura di E. Mmartellozzo Forin, Padova 1970.

Acta graduum academicorum Gymnasii Patavini ab anno 1538 ad annum 1550, t. III, parte 3, a cura di E. Martellozzo Forin, Padova 1971.

Acta graduum academicorum Gymnasii Patavini ab anno 1551 ad annum 1565, a cura di E. Dalla Francesca e E. Veronese, t. IV, parte 1, Roma-Padova 2001.

Acta graduum academicorum Gymnasii Patavini ab anno 1566 ad annum 1600 (1566-1575), a cura di E. Martellozzo Forin, Roma-Padova 2008.

Acta graduum academicorum Gymnasii Patavini ab anno 1566 ad annum 1600 (1576-1590), a cura di E. Martellozzo Forin, Roma-Padova 2008.

Archiwum nacji polskiej w Uniwersytecie Padewskim, t. I. Metryka nacji polskiej w Uniwersytecie Padewskim (1592-1745), do druku przyg. H. Barycz, indeks osób K. Targosz, Wrocław-Warszawa-Kraków-Gdańsk 1971.

Giedroyć F., Źródła biograficzno-bibliograficzne do dziejów medycyny w dawnej Polsce, Warszawa 1911.

Kromer M., De origine et rebus gestis Polonorum, Basilea 1568.

Windakiewicz S., Materiały do historii Polaków w Padwie, „Archiwum do dziejów literatury i oświaty w Polsce", t. 7, 1891.

Literatura:

Barycz H., Benedykt z Koźmina, [w:] PSB, t. 1, Kraków 1935.

Barycz H., Bodzęcin (z Bodzęcina) Mikołaj, [w:] PSB, t. 2, Kraków 1936.

Barycz H., Buchowski Andrzej, [w:] PSB, t. 3, Kraków 1937. 
Barycz H., Draski Adam, [w:] PSB, t. 5, Kraków 1939-1946.

Barycz H., Glicius Marcin, [w:] PSB, t. 8, Wrocław-Kraków-Warszawa 1959-1960.

Barycz H., Historia szkót nowodworskich od zalożenia do reformy H. Koltataja (1588-1777), Kraków 1988.

Barycz H., Historia Uniwersytetu Jagiellońskiego w epoce humanizmu, Kraków 1935.

Barycz H., Maricjusz Szymon, [w:] PSB, t. 20, Wrocław-Warszawa-Kraków-Gdańsk 1975.

Barycz H., Marcin z Ujazdu, [w:] PSB, t. 19, Wrocław-Warszawa-Kraków-Gdańsk 1974.

Barycz H., Polacy na studiach w Rzymie w epoce Odrodzenie (1440-1600), Kraków 1938.

Barycz H., Spojrzenia w przeszłość polsko-włoskq, Wrocław-Warszawa-Kraków 1965.

Barycz H., Z epoki renesansu, reformacji i baroku. Prqdy-idee-ludzie-ksiażki, Warszawa 1971.

Bednarski S., Stanisława Warszewickiego pochodzenie, młodość, studia w Wittenberdze i Padwie,

[w:] Studia z dziejów kultury, red. H. Barycz i J. Hulewicz, Warszawa 1949.

Biliński B., Tradizioni italiane all'Università Jagellonica di Cracovia, Wrocław-Warszawa-Kraków 1967.

Birkenmajer A., Brożek (Broscius) Jan, [w:] PSB, t. 3, Kraków 1937.

Brugi B., I giuresconsulti italiani del secolo XVI, [w:] Per la storia della giurisprudenza e delle università italiane. Saggi, Torino 1915.

Burckhardt J., Kultura Odrodzenia we Włoszech. Próba ujęcia, Warszawa 1961.

Burke P., Kultura i spoleczeństwo w renesansowych Włoszech, Warszawa 1991.

Chachaj M., Studia zagraniczne Jana Zamoyskiego (fakty, domysty, nieporozumienia), „Czasy Nowożytne", t. 26, 2013.

Chrzanowski I., Kot S., Humanizm i reformacja w Polsce, Lwów 1927.

Cytowska M., Janicki Klemens, [w:] PSB, t. 10, Wrocław-Warszawa-Kraków 1962.

Czapliński W., Ossoliński Zbigniew, [w:] PSB, t. 24, Wrocław-Warszawa-Kraków-Gdańsk 1979.

Ćwikliński L., O wawrzynie doktorskim i poetyckim Klemensa Janickiego, „Rozprawy Wydziału Filologicznego Polskiej Akademii Nauk w Krakowie”, t. 58, nr 6, 1919.

Ćwikliński L., Padwa i Polska, Warszawa 1922.

Davi M.R., La vita e le opere di Bernardino Tomitano, [w:] Gli studenti nella storia dell'Università di Padova, a cura di F. Piovan, Padova 2002.

Davi M.R., Bernardino Tomitano filosofo, medico e letterato, Trieste 1995.

Delumeau J., Cywilizacja Odrodzenia, Warszawa 1987.

Dupuigrenet Desroussilles F., L'università di Padova dal 1405 al concilio di Trento, [w:] Storia della cultura veneta dal primo Quattrocento al concilio di Trento, vol. 1/2 Vicenza 1980.

Fedalto G., Studenti stranieri a Venezia e a Padova 1550-1700, [w:] Storia della cultura veneta. Il seicento, vol 4/2, Vicenza 1984.

Gajda Z., Lepiarczyk J., Łopacki Jacek Augustyn, [w:] PSB, t. 18, Wrocław-Warszawa-KrakówGdańsk 1973.

Gajda Z., Jacek Augustyn Lopacki. Studium z dziejów kultury medycznej w Krakowie w XVIII w., Wrocław-Warszawa-Kraków 1969.

Garin E., La cultura del Rinascimento, Bari 1967.

Gąsiorowski S., i Kapral M., Sykst (Sykstus, Syxt, właśc. Mrzygłód), [w:] PSB, t. 46, Warszawa-Kraków 2009-2010.

Gmiterek H., Starnigel (Sterngel) Staryngelowicz, Starynglowicz) Zachariasz, [w:] PSB, t. 42, Warszawa-Kraków 2003-2004.

Hajdukiewicz L., Goliniusz Błażej Bazyli, [w:] PSB, t. 8, Wrocław-Kraków-Warszawa 19591960.

Hajdukiewicz L., Goliński Grzegorz, [w:] PSB, t. 8, Wrocław-Kraków-Warszawa 1959-1960.

Hajdukiewicz L., Halicjusz Szymon, [w:] PSB, t. 9, Wrocław-Kraków-Warszawa 1960-1961. 
Hajdukiewicz L., Kucharski Andrzej, [w:] PSB, t. 26, Wrocław-Warszawa-Kraków-Gdańsk-Łódź 1981.

Hajdukiewicz L., Mareniusz (Marennius) Stanisław, [w:] PSB, t. 19, Wrocław-Warszawa-Kraków-Gdańsk 1974.

Hajdukiewicz L., Racki (Radzki) Jan, [w:] PSB, t. 29, Wrocław-Warszawa-Kraków-Gdańsk-Łódź 1986.

Historia nauki polskiej, pod red. B. Suchodolskiego, t. 6, Dokumentacja bio-bibliograficzna, oprac. L. Hajdukiewicz. Indeks biograficzny tomu 1/2, Wrocław 1974.

Kantak K., Franciszkanie polscy, t. 2 1517-1795, Kraków 1938.

Kiljańczyk-Zięba J., Czcionkq i piórem - Jan Januszewski w roli pisarza i tłumacza, Kraków 2007.

Kot S., Polska złotego wieku a Europa. Studia i szkice, Warszawa 1987.

Kot S., Venezia vista dai Polacchi nel corso dei secoli, Venezia 1947.

Lachs J., Krakowskie księgozbiory lekarskie, „Archiwum do dziejów literatury i oświaty w Polsce”, t. 13, 1914.

Lane F., Storia di Venezia, Torino 1978.

Lenart M., Studenti Polacchi a Padova e loro mecenatismo in patria, [w:] Mecenati, artisti e pubblico nel Rinascimento, a cura di L. Secchi Tarugi, Firenze 2011.

Lewicka-Kamińska A., Biblioteka Jagiellońska w latach 1492-1655, [w:] Historia Biblioteki Jagiellońskiej, t. I 1364-1775, pod red. I. Zarębskiego, Kraków 1966.

Łempicki S., Il cancelliere Giovanni Zamoyski di Padova e l'università, [w:] Omaggio dell'Accademia Polacca di Scienze e Lettere all'Università di Padova nel settimo centenario della sua fondazione, Cracovia 1922.

Łempicki S., Działalność Jana Zamoyskiego na polu szkolnictwa 1573-1605, Kraków 1921.

Łętowski L., Katalog biskupów, prałatów i kanoników krakowskich, t. 2, Kraków 1852; t. 3, Kraków 1852.

McCuaig W., Andrzej Patrycy Nidecki, Carlo Sigonio, Onofrio Panvinio i nacja polska na uniwersytecie padewskim „Odrodzenie i Reformacja w Polsce”, t. 32, 1987.

Marangoni G., Lazzaro Bonamico e lo studio Padovano, „Nuovo Archivio Veneto”, t. 2, 1901.

Maver G., I Polacchi all'Università di Padova, [w:] Il nono cinquantenario della nascità di Niccolò Copernico, Roma 1923.

Michalewiczowa M., Piotrowski Łukasz h. Junosza, [w:] PSB, t. 26, Wrocław-Warszawa-Kraków-Gdańsk-Lódź 1981.

Muratori L.M., Vita Carli Sigonii, [w:] C. Sigonius, Opera omnia edita et inedita, vol. 1, Mediolani 1732.

Nowacki J., Dzieje archidiecezji poznańskiej, t. 2, Archidiecezja poznańska w granicach historycznych i jej ustrój, Poznań 1964.

Obrębski A., Dziennik z lat 1561-1588 dyplomaty i biskupa płockiego Piotra Dunina-Wolskiego, „Biuletyn Biblioteki Jagiellońskiej”, R. 42, 1992.

Piovan F., Per la biografia di Lazzaro Bonamico. Ricerche sul periodo dell'insegnamento padovano (1530-1552), Trieste 1988.

Poczet rektorów Uniwersytetu Jagiellońskiego 1440-2000, Kraków 2000.

Poppi A., Ricerche sulla teologia e la scienza nella scuola padovana del Cinque e Seicento, Catanzaro 2001.

Procacci G., Storia degli Italiani, t. 2, Roma-Bari 1977.

Przyboś A., Akademia Krakowska w drugiej polowie XVII w., [w:] Dzieje Uniwersytetu Jagiellońskiego w latach 1364-1764, t. I, pod red. K. Lepszego, Kraków 1964.

Quirini-Popławska D., I visitatori Polacchi del museo di oggetti naturali di Ulisses Aldrovandi, [w:] Commentationes historicae, Warszawa-Kraków 1988. 
Rossetti L., Dottorati Polacchi a Padova dal 1600 al 1744 nel Sacro Collegio dei filosofi e medici di Padova (dall'Archivio Antico dell'Università), [w:] Relazioni tra Padova e la Polonia, Padova 1964.

Rossi G., Panciroli Guido, [w:] Dizionario Biografico degli Italiani, t. 80, Roma 2014.

Rubczyński W., Tracie di studi filosofici compiuti di Polacchi a Padova verso la fine del Cinquecento, [w:] Omaggio dell'Accademia Polacca di Scienze e Lettere all'Università di Padova nell settimo centenario della sua fondazione, Cracovia 1922.

Santarelli D., Navagero Bernardo, [w:] Dizionario Biografico degli Italiani, t. 78, Roma 2013.

Scienza e filosofia all'università di Padova nel Quattrocento, a cura di A. Poppi, Trieste 1983.

Simeoni L., Documenti sulla vita e la biblioteca di Carlo Sigonio, ,Studi e memorie della storia e dell'Università di Bologna", t. 11, 1933.

Ślaski J., Marian Leżeński - padewczyk zapomniany, „Odrodzenie i Reformacja w Polsce”, t. 48, 2004, s. 65-93.

Tiraboschi G., Storia della letteratura italiana, t. 7, Firenze 1810.

Tomasi F., Zendri C., Mantova Benevides Marco, Dizionario Biografico degli Italiani, t. 69, Roma 2007.

Urban W., Akademia Krakowska $w$ dobie reformacji i wczesnej kontrreformacji (1549-1632), [w:] Dzieje Uniwersytetu Jagiellońskiego, t. I, Kraków 1964, s. 253-307.

Windakiewicz S., Padwa. Studyum z dziejów cywilizacji polskiej, „Przegląd Polski”, R. 25, t. 3, 1891.

Wojciecha z Kalisza Szkoła Lenartowska, ed. S. Kot, „Archiwum do dziejów kultury i oświaty w Polsce", t. 13, 1914, s. 283-327.

Inne:

Enciclopedia italiana di scienze, lettere ed arti, t. 24, Roma 1934-1943.

Estreicher K., Bibliografia polska, t. 12, Kraków 1891; t. 14, Kraków 1898; t. 17, Kraków 1899; t. 26, Kraków 1915; t. 28, Kraków 1930; t. 31, Kraków 1936; t. 34, Kraków 1951; t. 35, Kraków 2000.

Katalog poloników XVI wieku Biblioteki Jagiellońskiej, red. M. Malicki, E. Zwinogrodzka, t. 3, Indeksy, Kraków 1995.

Malicki M., Catalogus librorum saeculi XVI qui in Bibliotheca Jagellonica Cracoviensi asservantur, t. 1, Baden-Baden 2002.

Volsciana. Katalog renesansowego księgozbioru Piotra Dunin Wolskiego, biskupa płockiego, oprac. A. Obrębski, Kraków 1999.

Wisłocki W., Katalog rękopisów Biblioteki Uniwersytetu Jagiellońskiego, cz. II, Kraków 1877-1881.

Danuta Quirini-Popławska, emer. prof. zw. dr hab. Uniwersytetu Jagiellońskiego, historyk. Zainteresowania badawcze: szeroko rozumiana historia i kultura późnośredniowiecznej i renesansowej Italii, powiązania polsko-włoskie i dzieje basenu Morza Śródziemnego. Autorka przeszło 200 publikacji naukowych (m.in. Sebastiano Montelupi, toscano, mercante e maestro della posta reale di Cracovia, Prato 1989; Urbs populissima, opulentissima, liberalissima. Mit czy rzeczywistość późnośredniowiecznej Wenecji?, Kraków 1997; Zwiqzki artystyczne dworu medycejskiego z Europq Środkowq w ostatniej ćwierci XVI wieku, Kraków 2002; Włoski handel czarnomorskimi niewolnikami w późnym średniowieczu, Kraków 2002; Italia mia. Studia z dziejów Italii i powiqzań polsko-włoskich w późnym Średniowieczu i Renesansie, Kraków 216). Organizator wielu konferencji krajowych i międzynarodowych, założyciel i kierownik studiów licencjackich na kierunku kulturoznawstwo-mediteraneistyka na UJ, redaktor wielu prac zbiorowych, odznaczona m.in. Krzyżem Kawalerskim Orderu Gwiazdy Solidarności Włoskiej przyznanym przez prezydenta Republiki Włoskiej Giorgia Napolitano w 2006 r. 
Krzysztof Frankowicz, mgr, absolwent historii Uniwersytetu Jagiellońskiego, wicedyrektor Biblioteki Jagiellońskiej do spraw Udostępniania Zbiorów, doktorant w Instytucie Kulturoznawstwa Wydziału Filozoficznego Akademii Ignatianum w Krakowie. Zajmuje się historią kultury polskiej i europejskiej oraz historią Biblioteki Jagiellońskiej. Jest autorem rozprawy (wespół z D. Quirini-Popławską) Dzieła padewskich profesorów medycyny (Gabriele Fallopia, Melchiorze Guilandini, Girolamo Mercuriale) w zbiorach Biblioteki Jagiellońskiej i ich proweniencja, [w:] Exemplis discimus. Księga jubileuszowa osiemdziesięciolecia Profesora Edwarda Potkowskiego, po red. P. Tafiłowskiego, Lublin 2012 oraz artykułu Zainicjowanie i znaczenie studiów nad językiem i literatura greckq na przełomie XV i XVI wieku w Akademii Krakowskiej, [w:] Innowacje w kulturze na przestrzeni wieków, pod red. J. Kołat, A. Świerczek, S. Wyszogrodzkiej, Kraków 2016. 


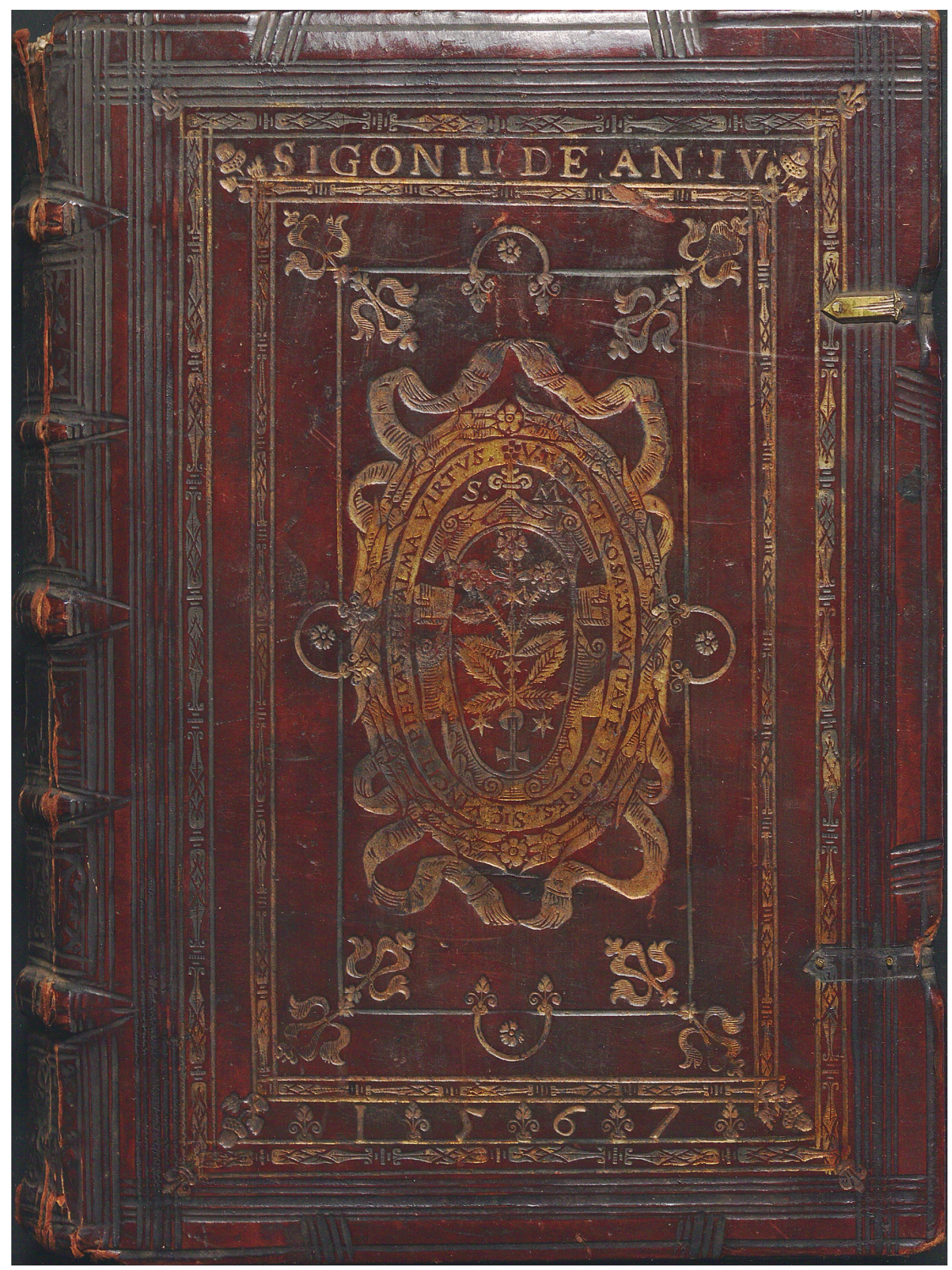

Ilustracja 1: Carlo Sigonio, De antiqvo ivre civivm Romanorvm libri dvo. Eivsdem De antiqvo ivre Italiae libri tres, Venetiae, MDLXIII (BJ St. Dr. Cim. 5910). 


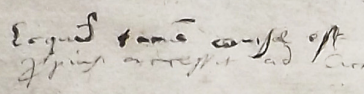

\title{
FRANCISCI ROBORTELLI
}

\author{
$V T$ I N E N S I S \\ D E
}

CONVENIENTIA SVPPVTATIONIS

LIVIANAE ANN. CVM MARMORIBVS

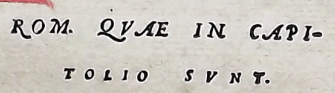

EIVSDEM DE ARTE, SIVE RATIONE corrigendi veteres Authores, difputatio .

EIVSDEM EMENDATIONVM

$$
\triangle A B R I \text { OVO. }
$$

Ad Clarifr. virum Ioannem Bernardi F. Donanum

Patritium Venetum.

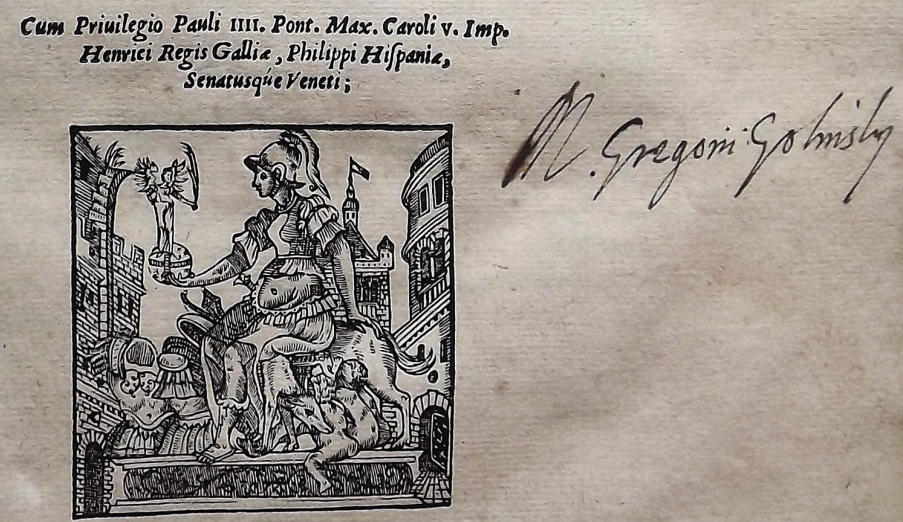

P A T A V I I, $\frac{\text { Apud Innocentium Olmum. }}{\text { M D LVII. }}$

Ilustracja 2: Francesco Robortello, De convenientia svppvtationis Livianae Ann. cvm marmoribvs ..., Patavium, MDLVII (BJ St. Dr. 393380 III). 


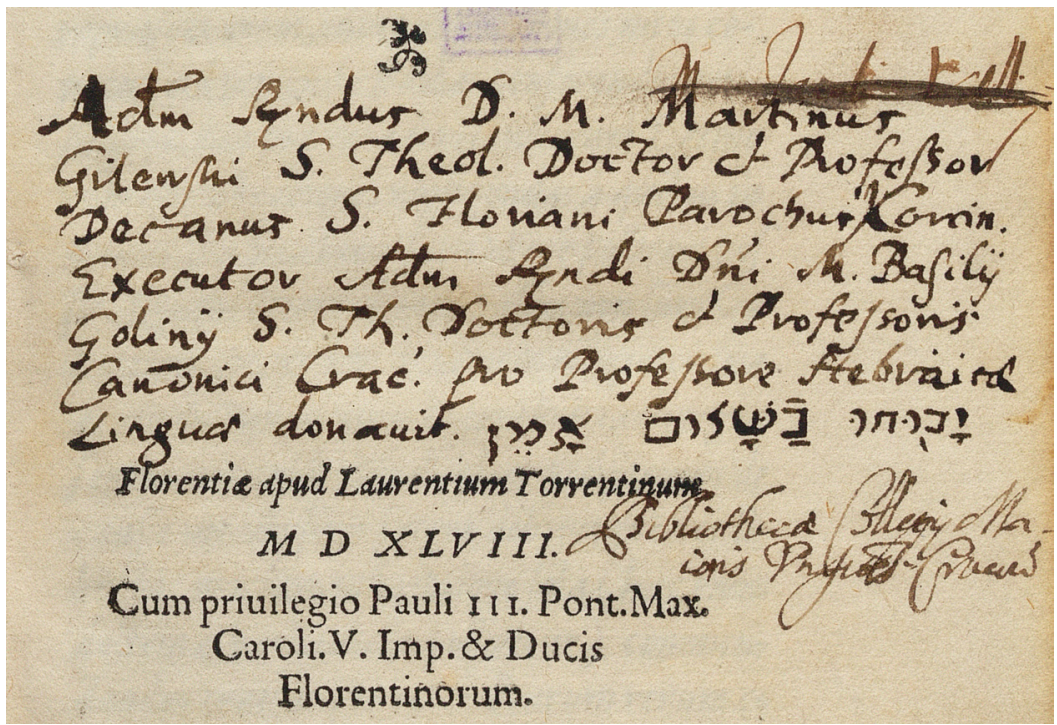

Ilustracja 3: Francesco Robortello, De historica facultate, disputatio Eiusdem Laconici ..., Florentia, MDXLVIII (BJ St. Dr. Neolatina 425-426). 


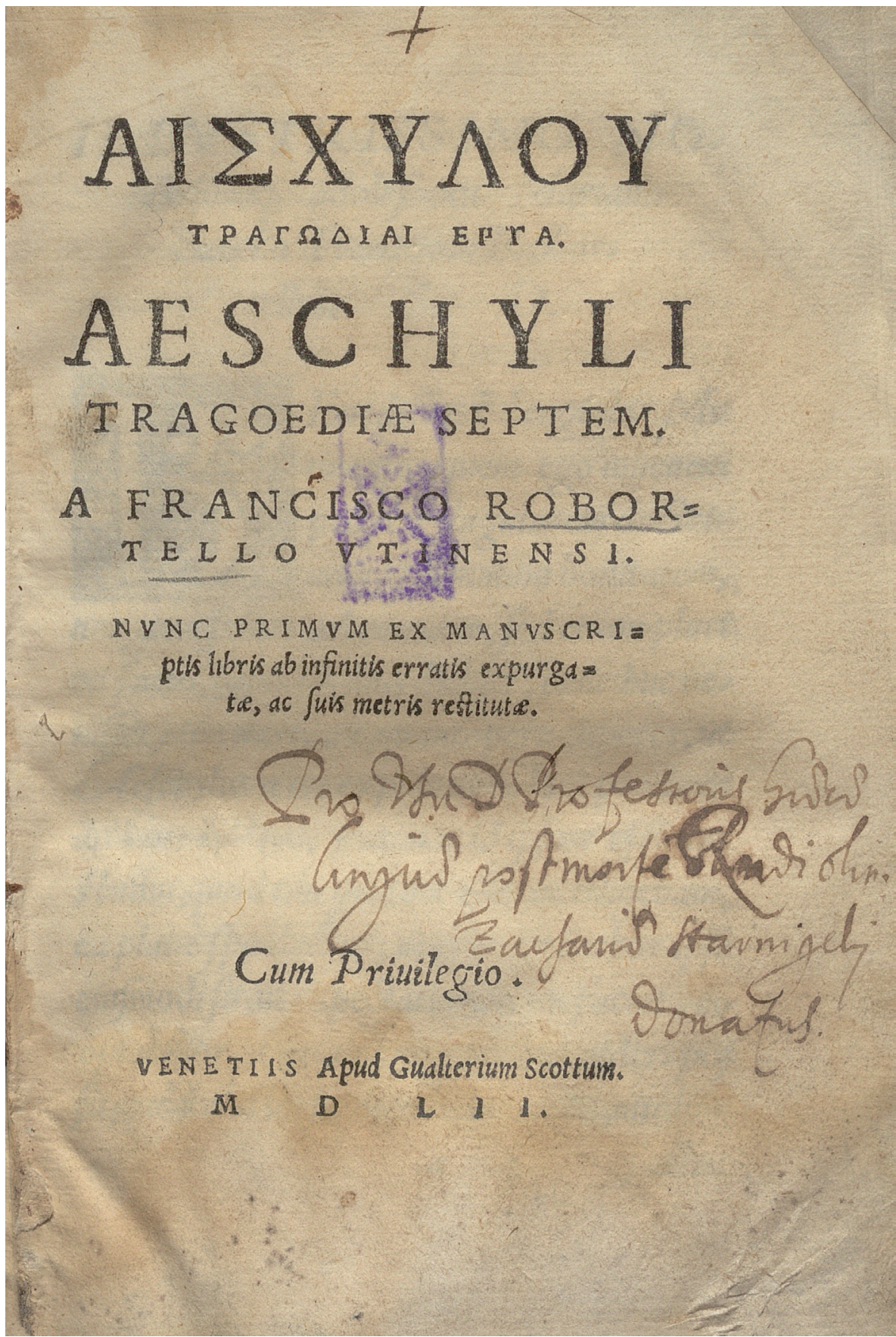

Ilustracja 4: Ajschylos, Aischylou Tragodiai epta. Aeschyli Tragoediae septem. A Francisco Robortello ..., Venetiae, MDLII (BJ St. Dr. Greka 28 (a). 


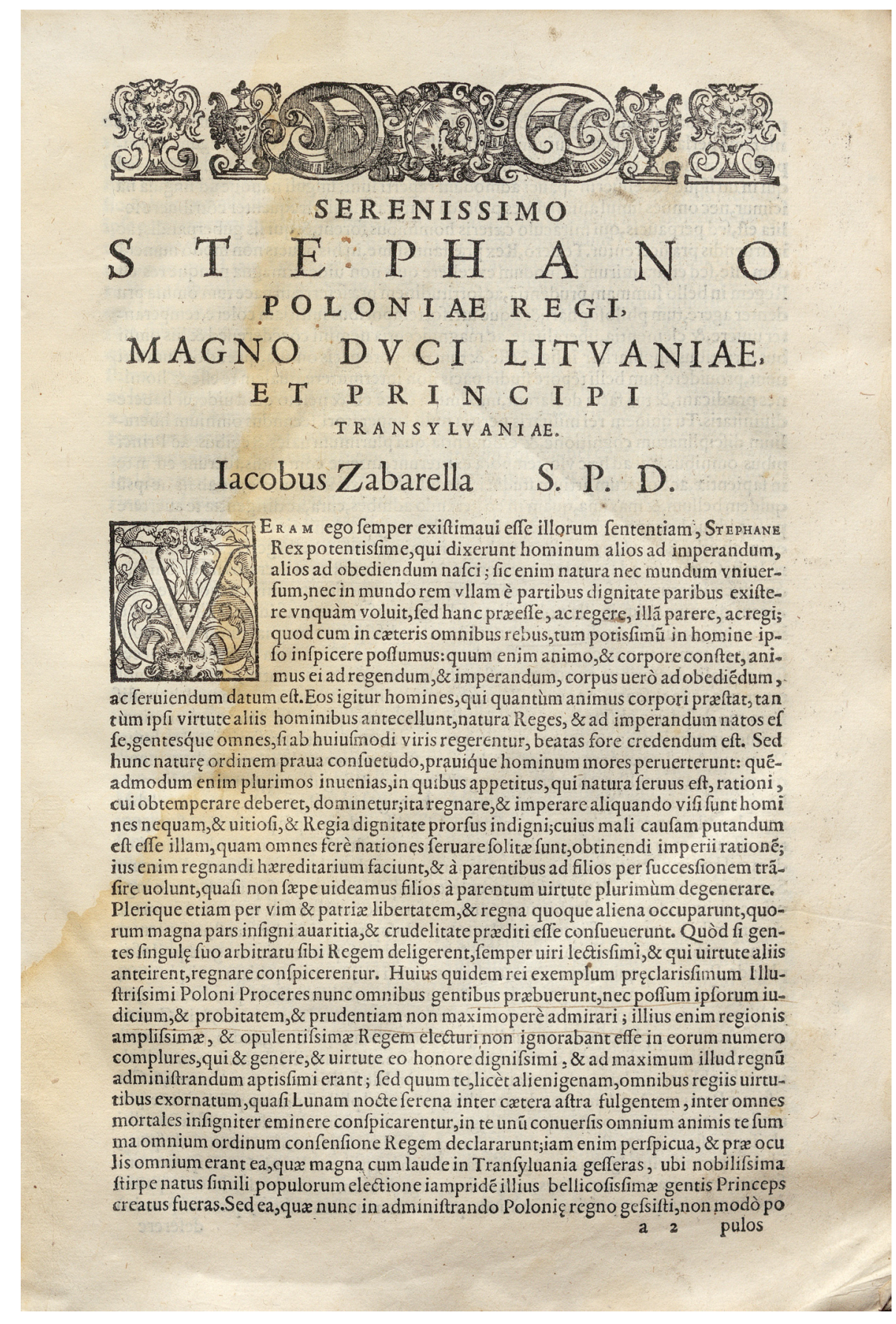

Ilustracja 5: Jacopo Zabarella, De rebvs natvralibvs libri XXX. Quibus quaestiones, quae ..., Colonia, cIcIcxc (BJ St. Dr. Cim. 8739-8740). 
C I (2. 16) rem uirtutem \& eruditionem mihi charifsimus, quo ego

7. 9 familiariter utor, hiftoriam à te fuperiore anno editam res Lum Polonicarum, non modò mihi legendam tradidit, fed etiam librum ipfum, ut fui effet amoris erga me monimentum, dono de dir. Legi igitur ftatim omnem, \& auidè quidem percurri . alliciebates nim me rerum uarietas ipfa : plurimum uerò me delectabat, ac ueluti in medio curfu defatigatum recreabat orationis tua fuauitas $\&$ puris tas, quam in ea defcribentla adhibuifti t tam enim politè,tam grauiter, tam copiofe \& eleganter omnia es perfecutus, ut qui in eo genere te' cum conferri pofsit, non uideam. Valde mihi probatur difputatio illa quidem fubtilis $\&$ doeta, quam ab initio libri habuifti de origine $\&$ an tiquitate Slauorum, unde tu Polonos tuos uerè ortos fribis, Quid ue ró potuit ingeniofius aut acutius dici de lingua ipfa, de moribus, de commigrationibus ipforum, quàm quod à te dictum fuit w ut erat hoc maximè neceflarium cognitu, antequam hiftoriam fcriberes, ita planè in co explicando non recentiores modò, fed ueteres omnes mihi uide. ris fuperaffe, nam de Gallis \& eorum origine multa Liuius \& Cæfar: de Germanis etiam : multa de Opicis \& Siculis, alijs' ${ }_{3}$ Græcis Thueydides: fed omnia perpufilla funt, fi cum ijs, quæà te ueterum teftimo. nio comprobata fcripta fuerunt, conferantur. Huc accedit, quod no. mina Slatíica tam aptè ad fonum Romanum redegifti, ut nihil incons cinnum, nihil durum, nihil af perum in ijs relictum fit: quod te exemplo Cxfaris, \& aliortm feciffe uideo, qui, ut fatis conftat, Dumnorigis, Orgetorigis, \& aliorum nomina quamplurima ita effinxerunt, ut ko. manorum aures non offenderent. Tam uerò apté efficta, praterquam quòd gratiora nobis funt, etiam ad memoriam uidentur effe firmiora: nec tamen à communi loquendi confuetudine ita recedunt, ut quiuis prouincialis ea non agnofeat. Sed haec leuia fortafsis funt $:$ illa multo maiora. Singulorum regum Polonix res geftas, Reipubl, formam \& mutationem omnem, procerum dignitatem \& autoritatem, comitio. rum habendorum rationem, fuffragị ius omne, legum fanciendarum caufas \& mores omnium populorum ita explicas, ut, quod in primis

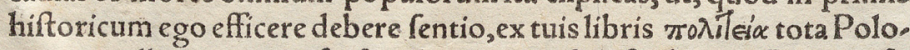
norum colligi ato agnofci, $\&$ ad ueterum philofophorum Platonis $\&$ Ariftotelis, qui de tota hac ciuili fcientia uberrimè fcripferunt, nore mam dijudicari polsit. Temporum feries praterea ita conftar uniuer. fa : caufx \& euentus rerum, ipfarum'q gerendarum ratio tam liquido apparent, ut nihil requirere, quamuis diligens $\&$ attentus lector pof fit amplius.Laudo etiam, quod nullam ullam ullius actionem priuati hominis perfecutus es, qua non effet cum publicis actionibus coniun 